\title{
LEVEL II SCOUR ANALYSIS FOR BRIDGE 25 (REDSTH00360025) on TOWN HIGHWAY 36, crossing the WEST BRANCH DEERFIELD RIVER, READSBORO, VERMONT
}

U.S. Geological Survey

Open-File Report 97-653

Prepared in cooperation with

VERMONT AGENCY OF TRANSPORTATION

and

FEDERAL HIGHWAY ADMINISTRATION 


\section{LEVEL II SCOUR ANALYSIS FOR BRIDGE 25 (REDSTH00360025) on TOWN HIGHWAY 36, crossing the WEST BRANCH DEERFIELD RIVER, READSBORO, VERMONT \\ By ROBERT H. FLYNN AND RONDA L. BURNS}

U.S. Geological Survey

Open-File Report 97-653

Prepared in cooperation with

VERMONT AGENCY OF TRANSPORTATION

and

FEDERAL HIGHWAY ADMINISTRATION 


\title{
U.S. DEPARTMENT OF THE INTERIOR BRUCE BABBITT, Secretary
}

\author{
U.S. GEOLOGICAL SURVEY \\ Gordon P. Eaton, Director
}

For additional information write to:

District Chief

U.S. Geological Survey 361 Commerce Way

Pembroke, NH 03275-3718
Copies of this report may be purchased from:

U.S. Geological Survey

Branch of Information Services

Open-File Reports Unit

Box 25286

Denver, CO 80225-0286 


\section{CONTENTS}

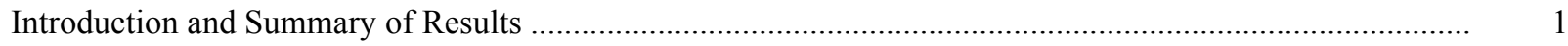

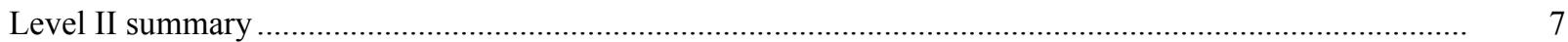

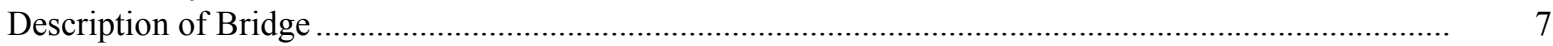

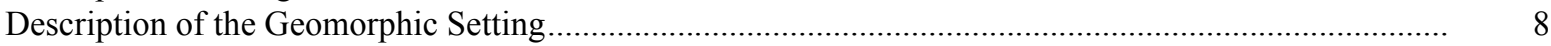

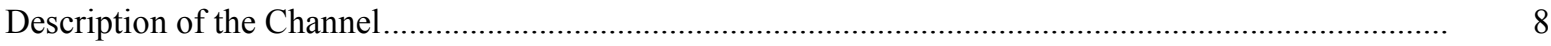

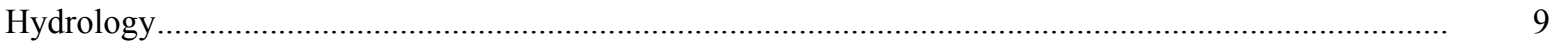

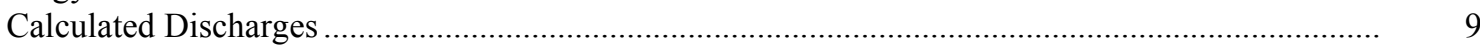

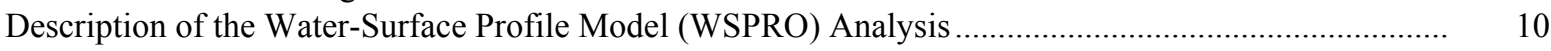

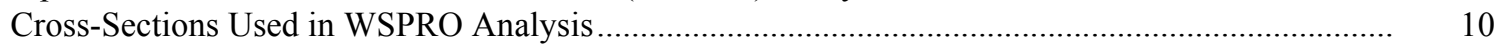

Data and Assumptions Used in WSPRO Model ...................................................................... 11

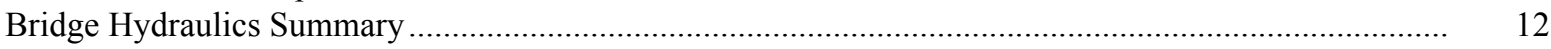

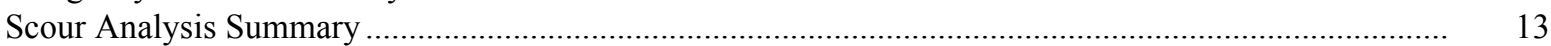

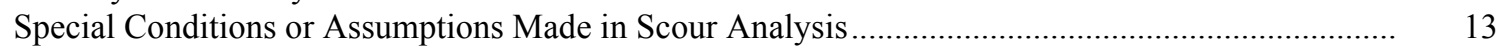

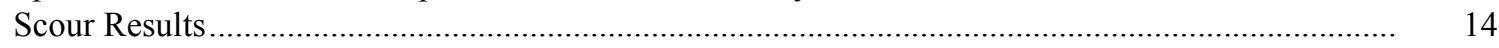

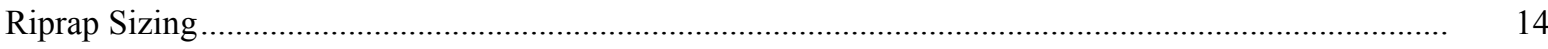

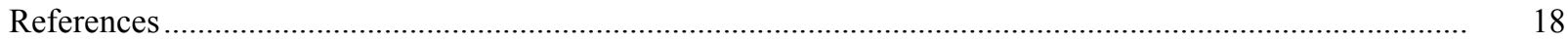

Appendixes:

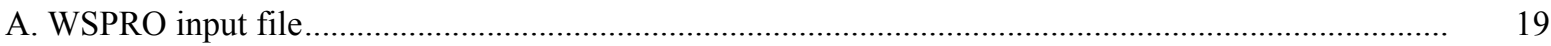

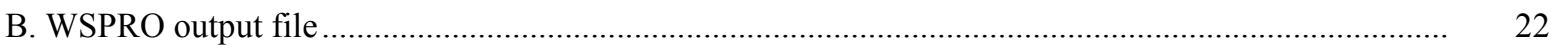

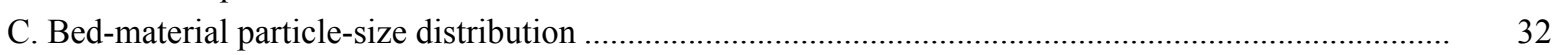

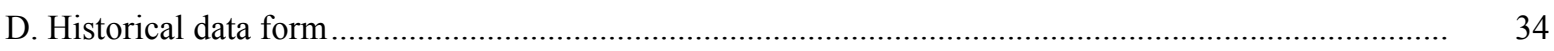

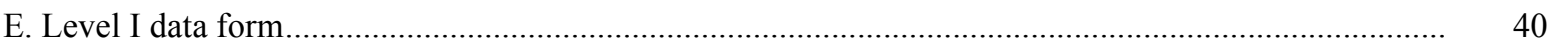

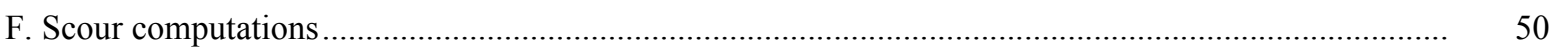

\section{FIGURES}

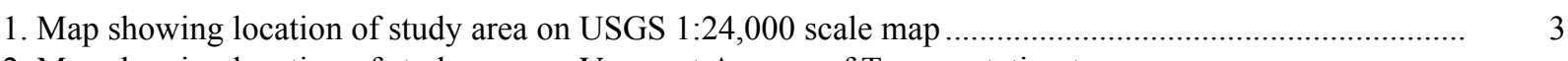

2. Map showing location of study area on Vermont Agency of Transportation town
highway map

3. Structure REDSTH00360025 viewed from upstream (August 1, 1996) ................................................. 5

4. Downstream channel viewed from structure REDSTH00360025 (August 1, 1996)............................. 5

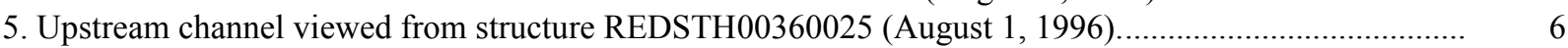

6. Structure REDSTH00360025 viewed from downstream (August 1, 1996)........................................ 6

7. Water-surface profiles for the 100- and 500-year discharges at structure REDSTH00360025 on Town Highway 36, crossing the West Branch Deerfield River,

Readsboro, Vermont.

8. Scour elevations for the 100- and 500-year discharges at structure

REDSTH00360025 on Town Highway 36, crossing the West Branch Deerfield River,

Readsboro, Vermont.

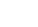

5

5

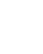

(




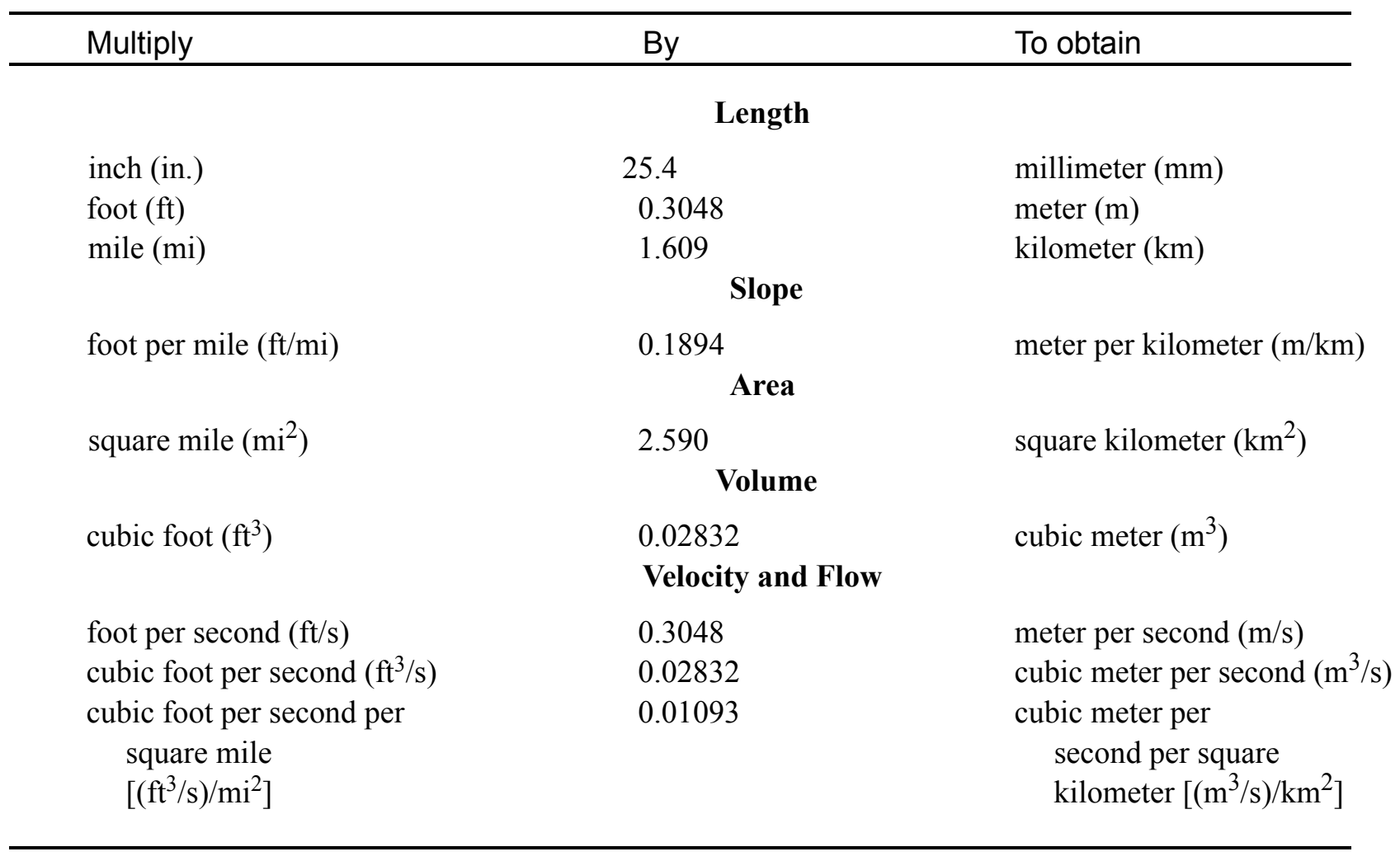

\section{OTHER ABBREVIATIONS}

$\begin{array}{lrlr}\mathrm{BF} & \text { bank full } & \text { LWW } & \text { left wingwall } \\ \mathrm{cfs} & \text { cubic feet per second } & \text { MC } & \text { main channel } \\ \mathrm{D}_{50} & \text { median diameter of bed material } & \text { RAB } & \text { right abutment } \\ \mathrm{DS} & \text { downstream } & \text { RABUT } & \text { face of right abutment } \\ \mathrm{elev} & \text { elevation } & \text { RB } & \text { right bank } \\ \mathrm{f} / \mathrm{p} & \text { flood plain } & \text { ROB } & \text { right overbank } \\ \mathrm{ft}^{2} & \text { square feet } & \text { RWW } & \text { right wingwall } \\ \mathrm{ft} / \mathrm{ft} & \text { feet per foot } & \text { TH } & \text { town highway } \\ \mathrm{JCT} & \text { junction } & \text { UB } & \text { under bridge } \\ \mathrm{LAB} & \text { left abutment } & \text { US } & \text { upstream } \\ \mathrm{LABUT} & \text { face of left abutment } & \text { USGS } & \text { United States Geological Survey } \\ \mathrm{LB} & \text { left bank } & \text { VTAOT Vermont Agency of Transportation } \\ \mathrm{LOB} & \text { left overbank } & \text { WSPRO } & \text { water-surface profile model }\end{array}$

In this report, the words "right" and "left" refer to directions that would be reported by an observer facing downstream. Sea level: In this report, "sea level" refers to the National Geodetic Vertical Datum of 1929-- a geodetic datum derived from a general adjustment of the first-order level nets of the United States and Canada, formerly called Sea Level Datum of 1929.

In the appendices, the above abbreviations may be combined. For example, USLB would represent upstream left bank. 


\title{
LEVEL II SCOUR ANALYSIS FOR BRIDGE 25 (REDSTH00360025) ON TOWN HIGHWAY 36, CROSSING THE WEST BRANCH DEERFIELD RIVER, READSBORO, VERMONT
}

\author{
By Robert H. Flynn and Ronda L. Burns
}

\section{INTRODUCTION AND SUMMARY OF RESULTS}

This report provides the results of a detailed Level II analysis of scour potential at structure REDSTH00360025 on Town Highway 36 crossing the West Branch Deerfield River, Readsboro, Vermont (figures 1-8). A Level II study is a basic engineering analysis of the site, including a quantitative analysis of stream stability and scour (U.S. Department of Transportation, 1993). Results of a Level I scour investigation also are included in Appendix E of this report. A Level I investigation provides a qualitative geomorphic characterization of the study site. Information on the bridge, gleaned from Vermont Agency of Transportation (VTAOT) files, was compiled prior to conducting Level I and Level II analyses and is found in Appendix D.

The site is in the Green Mountain section of the New England physiographic province in south-central Vermont. The $14.5-\mathrm{mi}^{2}$ drainage area is in a predominantly rural and forested basin. In the vicinity of the study site, the surface cover is pasture on the upstream right bank and forest on the upstream left bank. The surface cover on the downstream right and left banks is primarily grass, shrubs and brush.

In the study area, the West Branch Deerfield River has an incised, sinuous channel with a slope of approximately $0.02 \mathrm{ft} / \mathrm{ft}$, an average channel top width of $65 \mathrm{ft}$ and an average bank height of $4 \mathrm{ft}$. The channel bed material ranges from gravel to boulders, with a median grain size $\left(\mathrm{D}_{50}\right)$ of $117 \mathrm{~mm}(0.383 \mathrm{ft})$. The geomorphic assessment at the time of the Level I and Level II site visit on August 1, 1996, indicated that the reach was stable.

The Town Highway 36 crossing of the West Branch Deerfield River is a 59-ft-long, twolane bridge consisting of one 57-foot concrete T-beam span (Vermont Agency of Transportation, written communication, September 28, 1995). The opening length of the structure parallel to the bridge face is $54 \mathrm{ft}$. The bridge is supported by vertical, concrete abutments with wingwalls. The channel is skewed approximately 50 degrees to the opening while the opening-skew-to-roadway is 30 degrees. 
During the Level I assessment, a scour hole approximately $2 \mathrm{ft}$ deeper than the mean thalweg depth was observed along the upstream right wingwall and a scour hole approximately $1 \mathrm{ft}$ deeper than the mean thalweg depth was observed along the downstream left wingwall. The scour protection measure at the site was type-2 stone fill (less than 36 inches diameter) at the downstream end of the downstream left wingwall, at the upstream end of the upstream right wingwall, at the downstream end of the right abutment, along the entire base length of the downstream right wingwall, along the upstream right bank and along the downstream left bank. A stone wall was noted along the upstream left bank. Additional details describing conditions at the site are included in the Level II Summary and Appendices D and E.

Scour depths and recommended rock rip-rap sizes were computed using the general guidelines described in Hydraulic Engineering Circular 18 (Richardson and others, 1995). Total scour at a highway crossing is comprised of three components: 1) long-term streambed degradation; 2) contraction scour (due to accelerated flow caused by a reduction in flow area at a bridge) and; 3 ) local scour (caused by accelerated flow around piers and abutments). Total scour is the sum of the three components. Equations are available to compute depths for contraction and local scour and a summary of the results of these computations follows.

Contraction scour for all modelled flows ranged from 0.0 to $0.6 \mathrm{ft}$. The worst-case contraction scour occurred at the incipient-overtopping discharge. Abutment scour ranged from 15.1 to $16.3 \mathrm{ft}$ along the left abutment and from 7.4 to $9.2 \mathrm{ft}$ along the right abutment. The worst-case abutment scour occurred at the incipient-overtopping and 500-year discharges for the left abutment and at the 500-year discharge for the right abutment. Additional information on scour depths and depths to armoring are included in the section titled "Scour Results". Scoured-streambed elevations, based on the calculated scour depths, are presented in

tables 1 and 2. A cross-section of the scour computed at the bridge is presented in figure 8 . Scour depths were calculated assuming an infinite depth of erosive material and a homogeneous particle-size distribution.

It is generally accepted that the Froehlich equation (abutment scour) gives "excessively conservative estimates of scour depths" (Richardson and others, 1995, p. 47). Usually, computed scour depths are evaluated in combination with other information including (but not limited to) historical performance during flood events, the geomorphic stability assessment, existing scour protection measures, and the results of the hydraulic analyses. Therefore, scour depths adopted by VTAOT may differ from the computed values documented herein. 


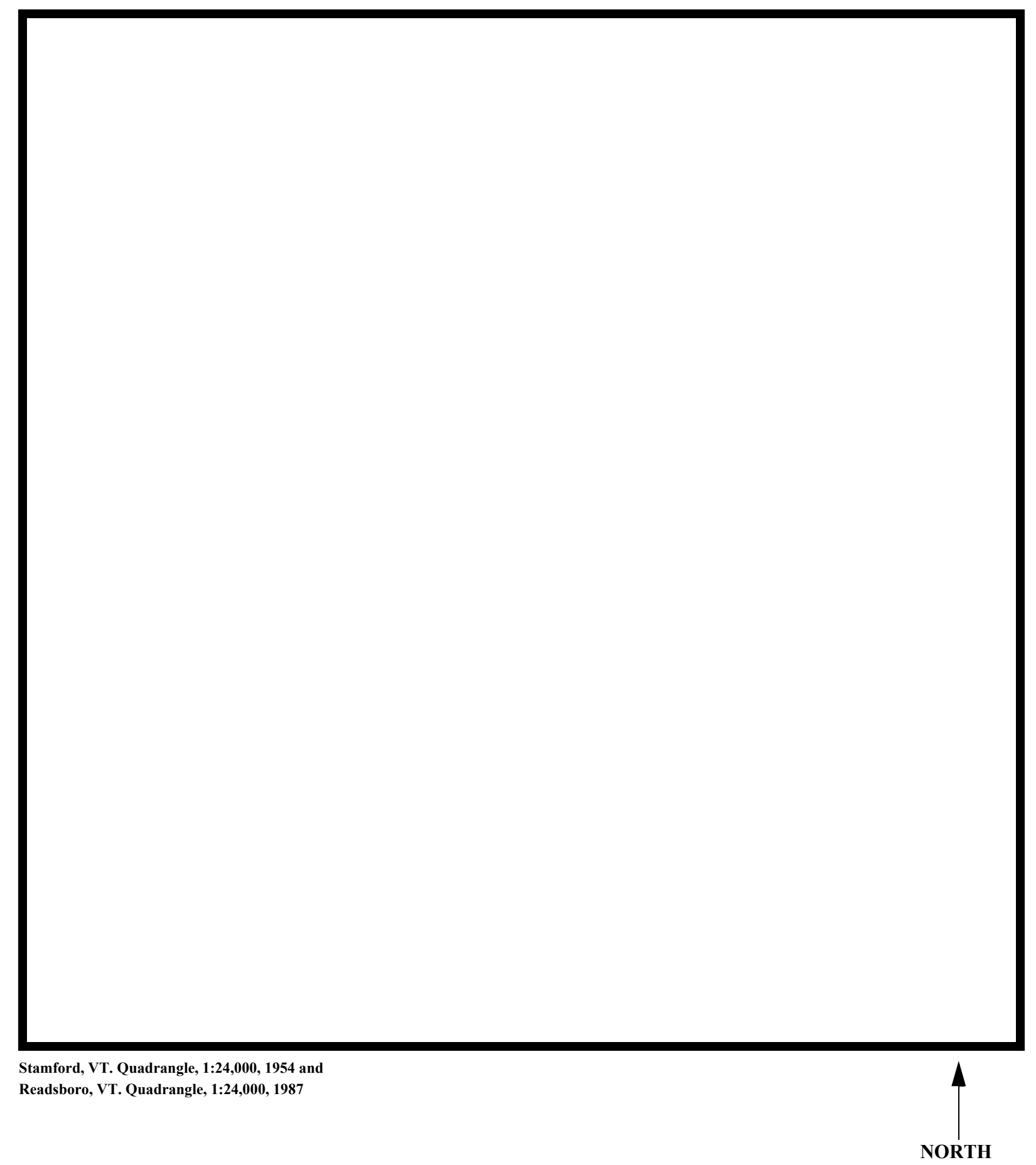

Figure 1. Location of study area on USGS 1:24,000 scale map. 
Figure 2. Location of study area on Vermont Agency of Transportation town highway map. 

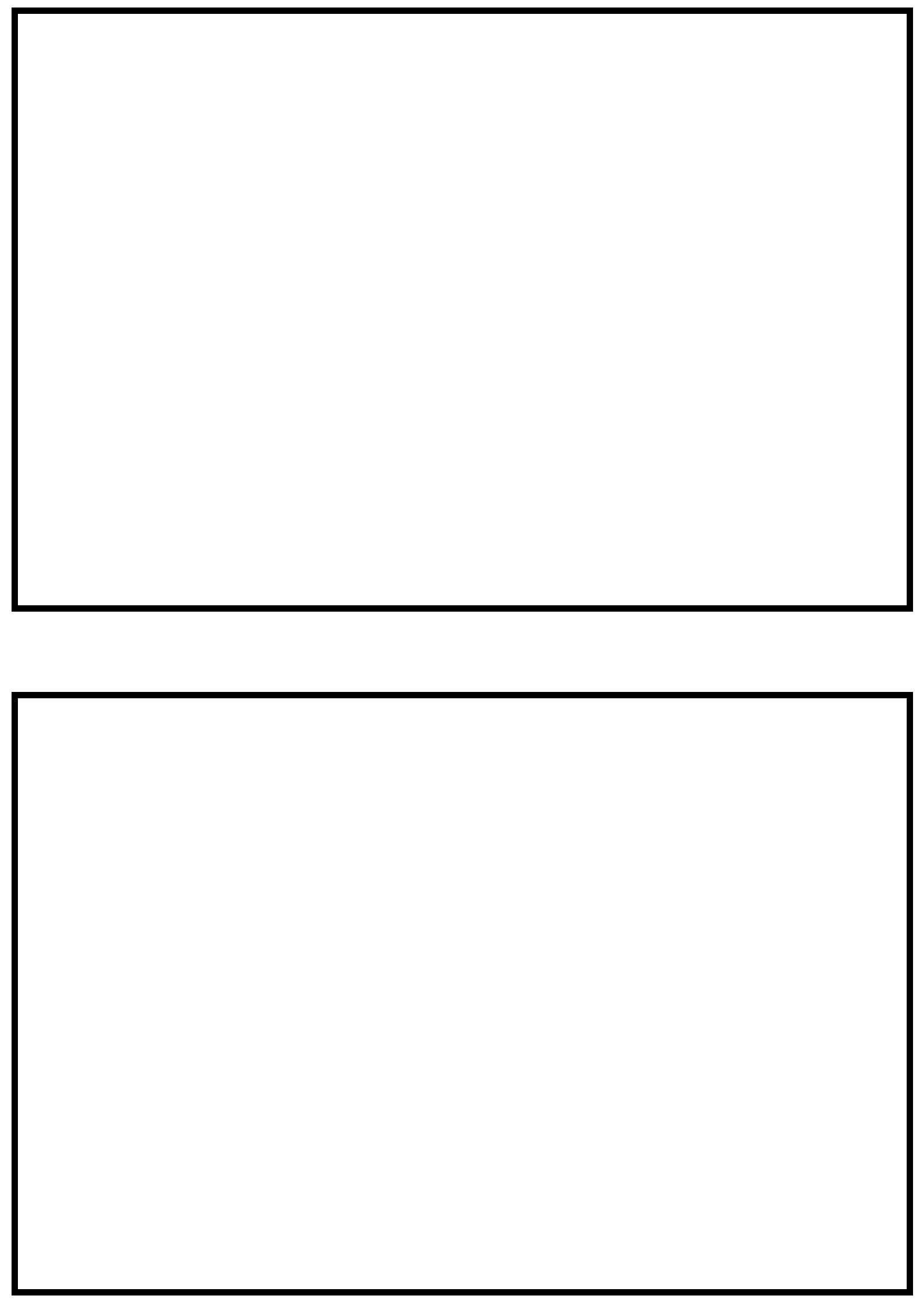

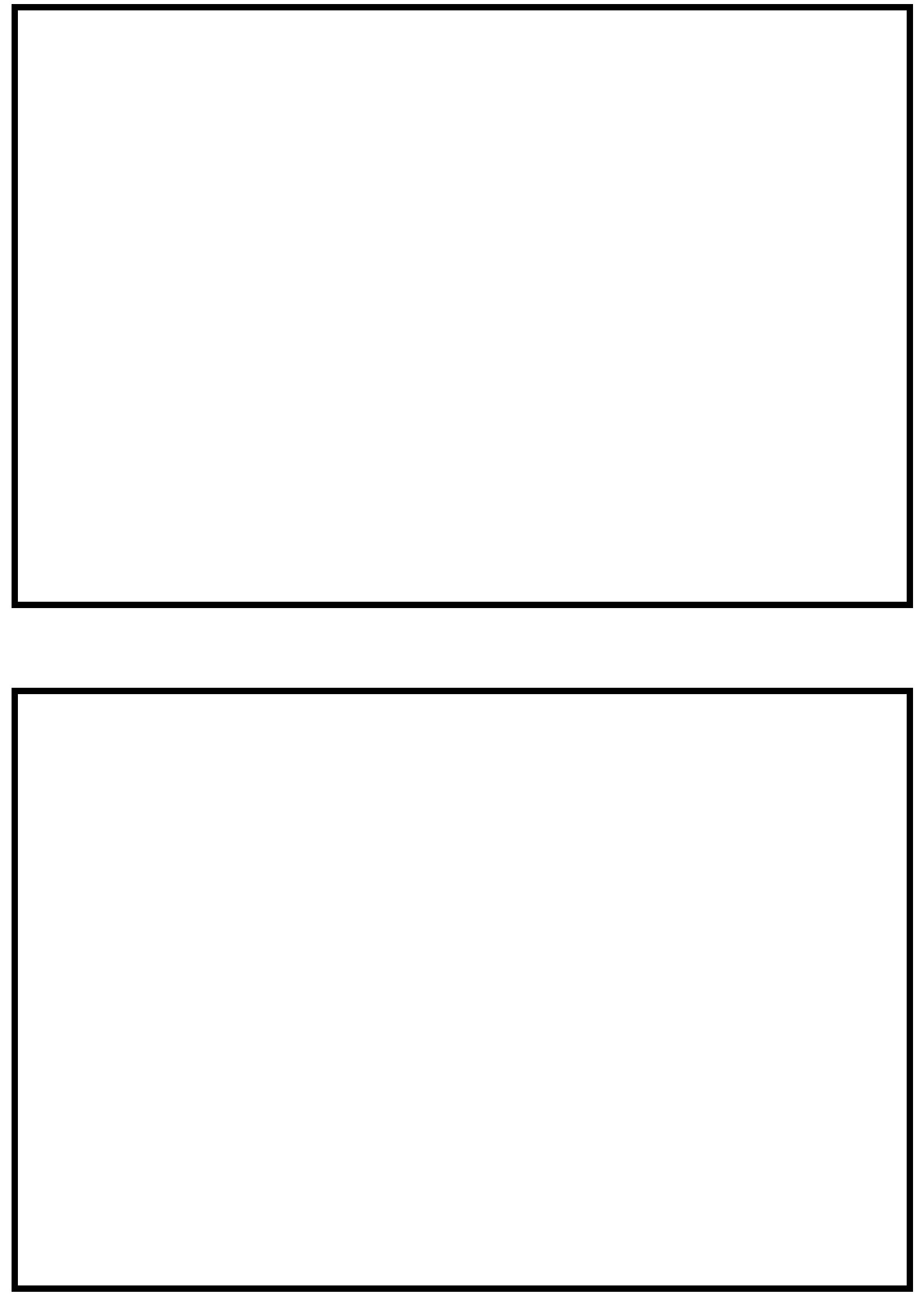


\section{LEVEL II SUMMARY}

\begin{tabular}{llllll} 
Structure Number & \multicolumn{2}{c}{ REDSTH00360025 } & Stream & \multicolumn{2}{c}{ West Branch Deerfield River } \\
& Roud & TH36 & District & Road
\end{tabular}

\section{Description of Bridge}

Bridge length $\stackrel{59}{\quad} \boldsymbol{f t}$ Bridge width $\stackrel{23.4}{f t}$ Max span length $\stackrel{57}{ } \boldsymbol{f t}$

Alignment of bridge to road (on curve or straight)

Vertical, concrete

Abutment type

Stone fill on abutment?

$$
\text { No }
$$

Embankment type

Curve, left; straight, right

Sloping

8/1/96 Type-

nacmintina. af nta... fill

2 stone fill at the downstream end of the downstream left wingwall, at

the upstream end of the upstream right wingwall, at the downstream end of the right abutment and

along the entire base length of the downstream right wingwall.

The abutments and wingwalls are concrete. A two feet

deep scour hole exists in front of the upstream right wingwall and a one foot deep scour hole exists

in front of the downstream left wingwall.

Yes

Is bridge skewed to flood flow according to. Yes ' survey? Angle

There is a severe channel bend in both the upstream and downstream reach The scour holes have developed in the locations where the flow impacts the wingwalls.

Debris accumulation on bridge at time of Level I or Level II site visit:

\begin{tabular}{|c|c|c|c|}
\hline & $\begin{array}{c}\text { Date of incnortion } \\
8 / 1 / 96\end{array}$ & $\begin{array}{l}\text { Percent of nlmumal } \\
\text { blocked inortzontatly }\end{array}$ & $\begin{array}{l}\text { Percent of } 0.1 . \ldots e l \\
\text { blocked verticatty }\end{array}$ \\
\hline & $8 / 1 / 96$ & 0 & 0 \\
\hline $\begin{array}{c}\text { Level II } \\
\text { upstream }\end{array}$ & \multicolumn{3}{|c|}{ Low. There is no debris in the channel near the bridge and the } \\
\hline
\end{tabular}

There is a point bar along the upstream left bank and a mid-channel bar underneath the bridge.

Doscriho any, foaturos noar ar at tho hridoo that mav affoct flow, (includo ahsorvation dato ). There is a bridge approximately $310 \mathrm{ft}$ downstream of this site, creating a potential for backwater at higher flows $(8 / 1 / 96)$. 


\section{Description of the Geomorphic Setting}

General topography The channel is located in a narrow, irregular flood plain within a moderate relief valley setting.

Geomorphic conditions at bridge site: downstream (DS), upstream (US)

Date of inspection $\quad 8 / 1 / 96$

DS left: $\quad$ Steeply sloped channel bank.

DS right: $\quad$ Moderately sloped channel bank to narrow flood plain and VT100

US left: $\quad$ Moderately sloped channel bank.

US right: $\quad$ Steeply sloped channel bank to narrow flood plain and VT100.

\section{Description of the Channel}

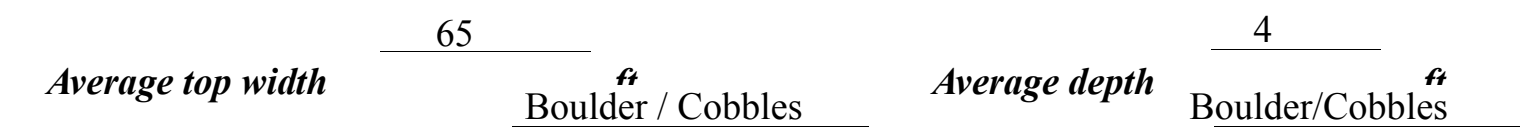

Predominant bed material

Bank material

Sinuous but stable

with non-alluvial channel boundaries and a narrow flood plain.

$8 / 1 / 96$

Vegetative co $1^{1}$ Grass, shrubs and brush

DS left: $\quad$ Trees and brush

DS right: Trees

US left: $\quad$ Trees and pasture

US right: $\quad$ Yes

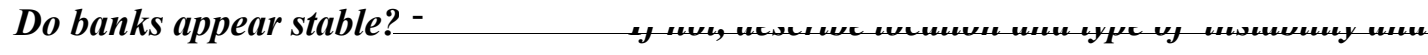

date of observation.

The assessment of

8/1/96 noted flow conditions are influenced by a point bar on the upstream left bank and a midDescribe any obstructions in channel and date of observation.

channel bar under the bridge as well as a bridge approximately $310 \mathrm{ft}$ downstream of this site. 


\section{Hydrology}

Drainage area $\frac{14.5}{m^{2}}{ }^{2}$

Percentage of drainage area in physiographic provinces: (approximate)

Physiographic province/section

New England/Green Mountain
Percent of drainage area 100

Is drainage area considered rural or urban? — Rural _ Describe any significant urbanization:

Is there a USGS gage on the stream of interest?

No

USGS gage description

USGS gage number

Gage drainage area $\mathrm{mi}^{2}$

$--$

\section{$--$}

USGS gage number
Gage drainage area

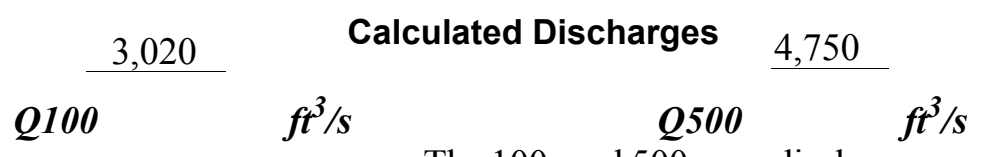

The 100- and 500-year discharges are based on flood

frequency estimates available from the VTAOT database. These values were selected due to the central tendency of the discharge frequency curve with others which were developed from empirical relationships and extended to the 500-year discharge

(Benson, 1962; Johnson and Tasker, 1974; FHWA, 1983; Potter, 1957a\&b; Talbot, 1887) 


\section{Description of the Water-Surface Profile Model (WSPRO) Analysis}

Datum for WSPRO analysis (USGS survey, sea level, VTAOT plans)

USGS survey

Datum tie between USGS survey and VTAOT plans

None.

Description of reference marks used to determine USGS datum. $\quad \underline{\mathrm{RM} 1 \text { is a chiseled X on top }}$

of the upstream end of the left abutment (elev. $501.51 \mathrm{ft}$, arbitrary survey datum). RM2 is a VTAOT

survey disk on top of the downstream right concrete rail on the downstream bridge (VT100) (elev. 496.90

$\mathrm{ft}$, arbitrary survey datum). RM3 is a chiseled X on top of the downstream end of the right abutment (elev.

$501.84 \mathrm{ft}$, arbitrary survey datum).

\section{Cross-Sections Used in WSPRO Analysis}

\begin{tabular}{|c|c|c|c|}
\hline $\begin{array}{l}{ }^{1} \text { Cross- } \\
\text { section }\end{array}$ & $\begin{array}{c}\text { Section } \\
\text { Reference } \\
\text { Distance } \\
\text { (SRD) in } \\
\text { feet }\end{array}$ & $\begin{array}{l}{ }^{2} \text { Cross-section } \\
\text { development }\end{array}$ & Comments \\
\hline EXIT2 & -502 & 1 & VT100 bridge exit section. \\
\hline FLV2 & -352 & 2 & $\begin{array}{l}\text { VT100 bridge Full-valley section (Templated from } \\
\text { EXIT2). }\end{array}$ \\
\hline DSBRG & -352 & 1 & VT100 bridge section. \\
\hline RDWY2 & -332 & 1 & VT100 Road Grade section. \\
\hline APPR2 & -257 & 2 & $\begin{array}{l}\text { Modelled Approach section of VT100 Bridge (Templated } \\
\text { from APTM2). }\end{array}$ \\
\hline APTM2 & -61 & 1 & TH36 exit section as surveyed (Used as a template). \\
\hline EXIT3 & -150 & 2 & TH36 Bridge exit section (Templated from APTM2). \\
\hline EXIT1 & -61 & 2 & TH36 Bridge exit section (As surveyed). \\
\hline FULLV & 0 & 2 & TH36 Full-valley section (Templated from EXIT1). \\
\hline BRIDG & 0 & 1 & TH36 Bridge section. \\
\hline RDWAY & 14 & 1 & TH36 Road grade section. \\
\hline APPRO & 76 & 2 & $\begin{array}{l}\text { Modelled TH36 Approach section (Templated from } \\
\text { APTEM). }\end{array}$ \\
\hline APTEM & 122 & 1 & TH36 approach section as surveyed (Used as a template). \\
\hline
\end{tabular}

${ }^{1}$ For location of cross-sections see plan-view sketch included with Level I field form, Appendix E. For more detail on how cross-sections were developed see WSPRO input file. 


\section{Data and Assumptions Used in WSPRO Model}

Hydraulic analyses of the reach were done by use of the Federal Highway Administration's WSPRO step-backwater computer program (Shearman and others, 1986, and Shearman, 1990). The analyses reported herein reflect conditions existing at the site at the time of the study. Furthermore, in the development of the model it was necessary to assume no accumulation of debris or ice at the site. Results of the hydraulic model are presented in the Bridge Hydraulic Summary, Appendix B, and figure 7.

Channel roughness factors (Manning's " $n$ ") used in the hydraulic model were estimated using field inspections at each cross section following the general guidelines described by Arcement and Schneider (1989). Final adjustments to the values were made during the modelling of the reach. Channel " $n$ " values for the reach ranged from 0.050 to 0.055 , and overbank " $n$ " values ranged from 0.045 to 0.065 .

Critical depth at the VT100 bridge exit section (EXIT2), approximately $500 \mathrm{ft}$ downstream of this site, was assumed as the starting water surface. This depth was computed by use of the slopeconveyance method outlined in the user's manual for WSPRO (Shearman, 1990). The slope used was $0.0158 \mathrm{ft} / \mathrm{ft}$, which was estimated from the topographic map (U.S. Geological Survey, 1954, 1987). This slope resulted in a normal depth slightly less than critical depth and WSPRO defaulted to critical depth. Critical depth in the downstream reach for the flows modelled is considered to be a satisfactory solution.

The surveyed approach section (APTEM) was moved along the approach channel slope $(0.0098 \mathrm{ft} / \mathrm{ft})$ to establish the modelled approach section (APPRO), one bridge length upstream of the upstream face as recommended by Shearman and others (1986). This location also provides a consistent method for determining scour variables.

For the 100-year and incipient-overtopping discharges, WSPRO assumes critical depth at the bridge section. Supercritical models were developed for these discharges. After analyzing both the supercritical and subcritical profiles for each discharge, it was determined that the water surface profile does pass through critical depth within the bridge opening. Thus, the assumptions of critical depth at the bridge are satisfactory solutions. 


\section{Bridge Hydraulics Summary}

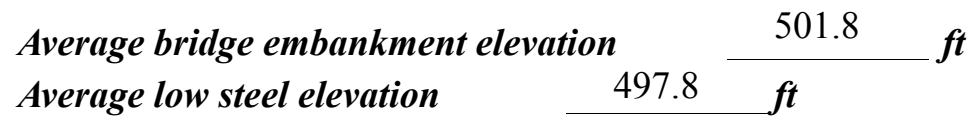

100-year discharge $\quad 3,020 \quad \mathrm{ft}^{3} / \mathrm{s}$

Water-surface elevation in bridge opening $\quad 493.5 \quad f t$

Road overtopping? ___ No Discharge over road ___ - $\mathrm{ft}^{3} / \mathrm{s}$

Area of flow in bridge opening $\quad 237 \quad \mathrm{ft}^{2}$

Average velocity in bridge opening $12.8 \quad \mathrm{ft} / \mathrm{s}$

$\begin{array}{llll}\text { Maximum WSPRO tube velocity at bridge } & 15.6 \mathrm{ft} / \mathrm{s}\end{array}$

Water-surface elevation at Approach section with bridge 497.3

Water-surface elevation at Approach section without bridge $\quad 494.4$

Amount of backwater caused by bridge

$2.9-i$

500-year discharge $\quad 4,750 \quad \mathrm{ft}^{3} / \mathrm{s}$

Water-surface elevation in bridge opening $\quad 498.0 \mathrm{ft}$

Road overtopping? ___ Yes Discharge over road __ $355 \mathrm{ft}^{3} / \mathrm{s}$

Area of flow in bridge opening $\quad 441 \quad \mathrm{ft}^{2}$

Average velocity in bridge opening $10.0 \mathrm{ft} / \mathrm{s}$

Maximum WSPRO tube velocity at bridge 11.5 /s

Water-surface elevation at Approach section with bridge 500.6

Water-surface elevation at Approach section without bridge $\quad 495.5$

Amount of backwater caused by bridge $5.1, t$

Incipient overtopping discharge $\quad 3,580 \mathrm{ft}^{3} / \mathrm{s}$

Water-surface elevation in bridge opening 494.1 it

Area of flow in bridge opening $\quad 265 \quad \mathrm{ft}^{2}$

Average velocity in bridge opening $\quad 13.5 \quad \mathrm{ft} / \mathrm{s}$

Maximum WSPRO tube velocity at bridge $\quad 16.2 \mathrm{ft} / \mathrm{s}$

Water-surface elevation at Approach section with bridge

Water-surface elevation at Approach section without bridge

498.2

Amount of backwater caused by bridge $\quad 3.4$ it 


\section{Scour Analysis Summary}

\section{Special Conditions or Assumptions Made in Scour Analysis}

Scour depths were computed using the general guidelines described in Hydraulic Engineering Circular 18 (Richardson and others, 1995). Scour depths were calculated assuming an infinite depth of erosive material and a homogeneous particle-size distribution.

Contraction scour for the 100-year and incipient-overtopping discharge was computed by use of the clear-water contraction scour equation (Richardson and others, 1995, p. 32, equation 20). At this site, the 500-year discharge resulted in unsubmerged orifice flow. Contraction scour at bridges with orifice flow is best estimated by use of the Chang pressureflow scour equation (oral communication, J. Sterling Jones, October 4, 1996). Thus, contraction scour was computed by use of the Chang equation (Richardson and others, 1995, p. 145-146). Results of this analysis are presented in figure 8 and tables 1 and 2. Additional estimates of contraction scour for the 500-year discharge were also computed by use of Laursen's clear-water scour equation and the results presented in Appendix F. The streambed armoring depths computed suggest that armoring will not limit the depth of contraction scour.

Abutment scour for the left abutment was computed by use of the Froehlich equation (Richardson and others, 1995, p. 48, equation 28). Variables for the Froehlich equation include the Froude number of the flow approaching the embankments, the length of the embankment blocking flow, and the depth of flow approaching the embankment less any roadway overtopping.

Scour at the right abutment was computed by use of the HIRE equation (Richardson and others, 1995, p. 49, equation 29) because the HIRE equation is recommended when the length to depth ratio of the embankment blocking flow exceeds 25 . The variables used by the HIRE abutment-scour equation are defined the same as those defined for the Froehlich abutment-scour equation. 


\section{Scour Results}

100-yr discharge 500-yr discharge

Contraction scour:

(Scour depths in feet)

Main channel

Live-bed scour

Clear-water scour

Depth to armoring

Left overbank

Right overbank

Local scour:

Abutment scour

16.3

16.39 .0

9.2

Left abutment

7.4-

Right abutment

Pier scour

Pier 1

Pier 2

$24.82 .8^{-}$

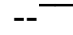

$---$

$15.1^{-}$

overtopping discharge

Pier 3

\section{Riprap Sizing}

Abutments:

Left abutment

Right abutment

Piers:

Pier 1

Pier 2

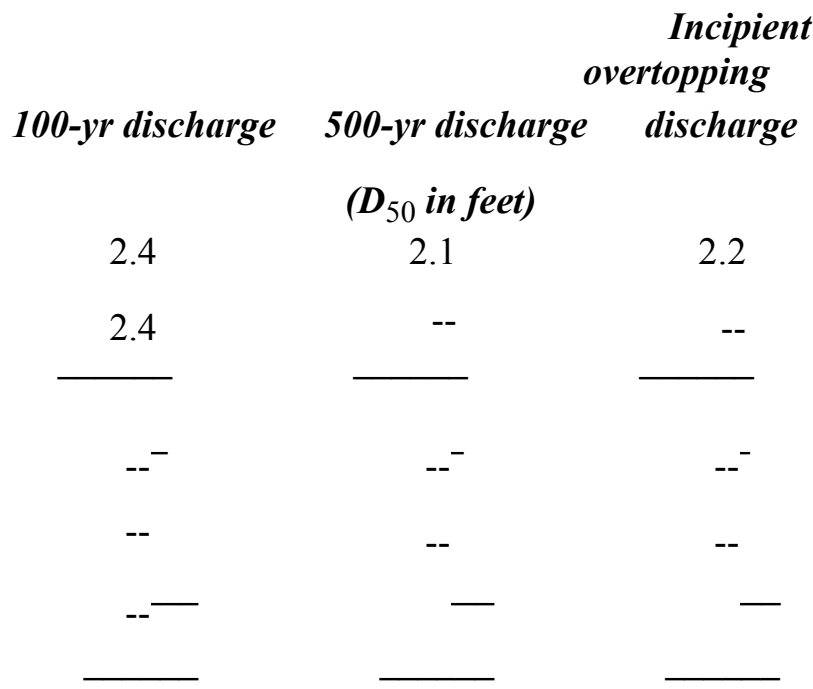




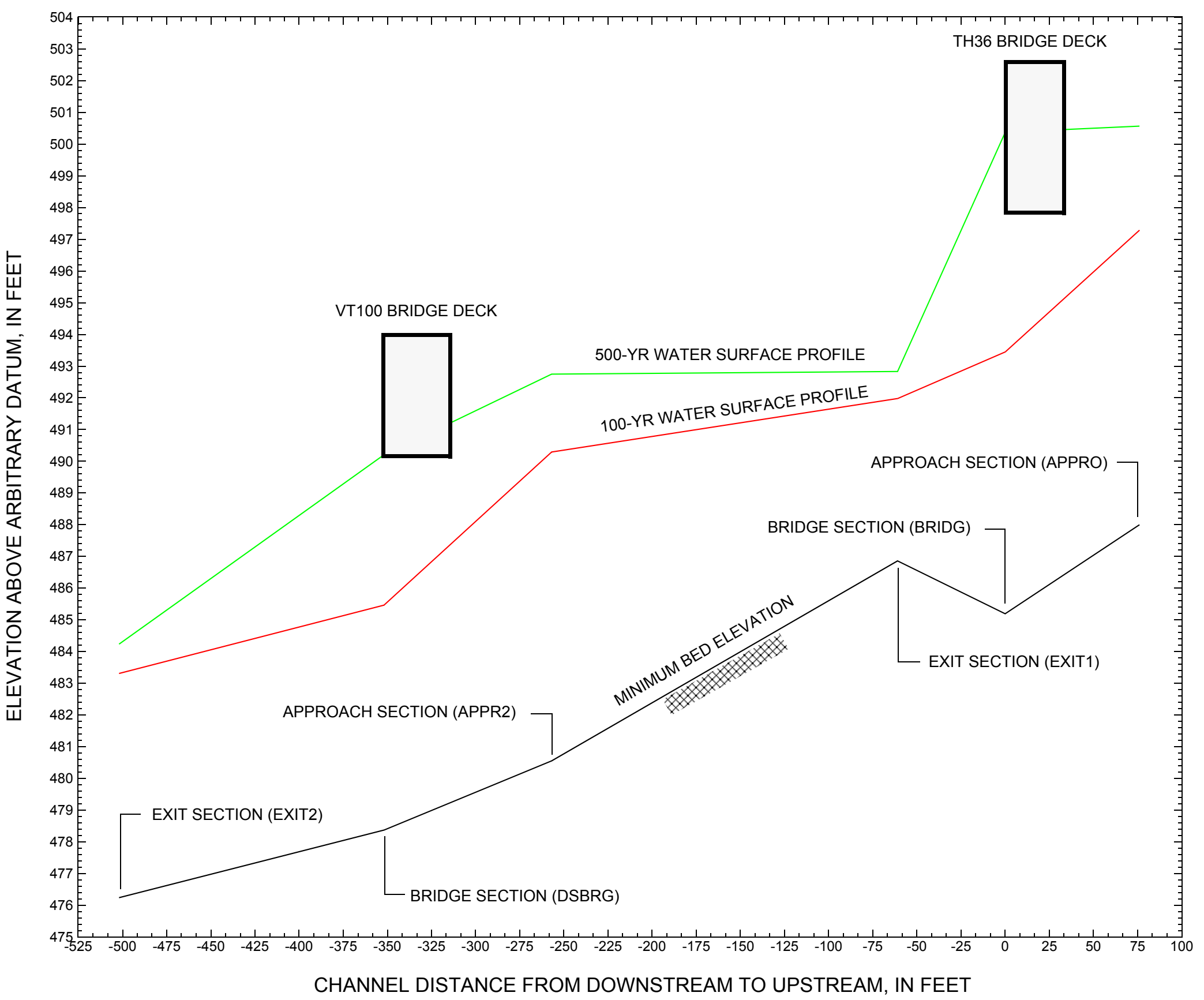

Figure 7. Water-surface profiles for the 100- and 500-yr discharges at structure REDSTH00360025 on Town Highway 36, crossing the West Branch Deerfield River, Readsboro, Vermont. 


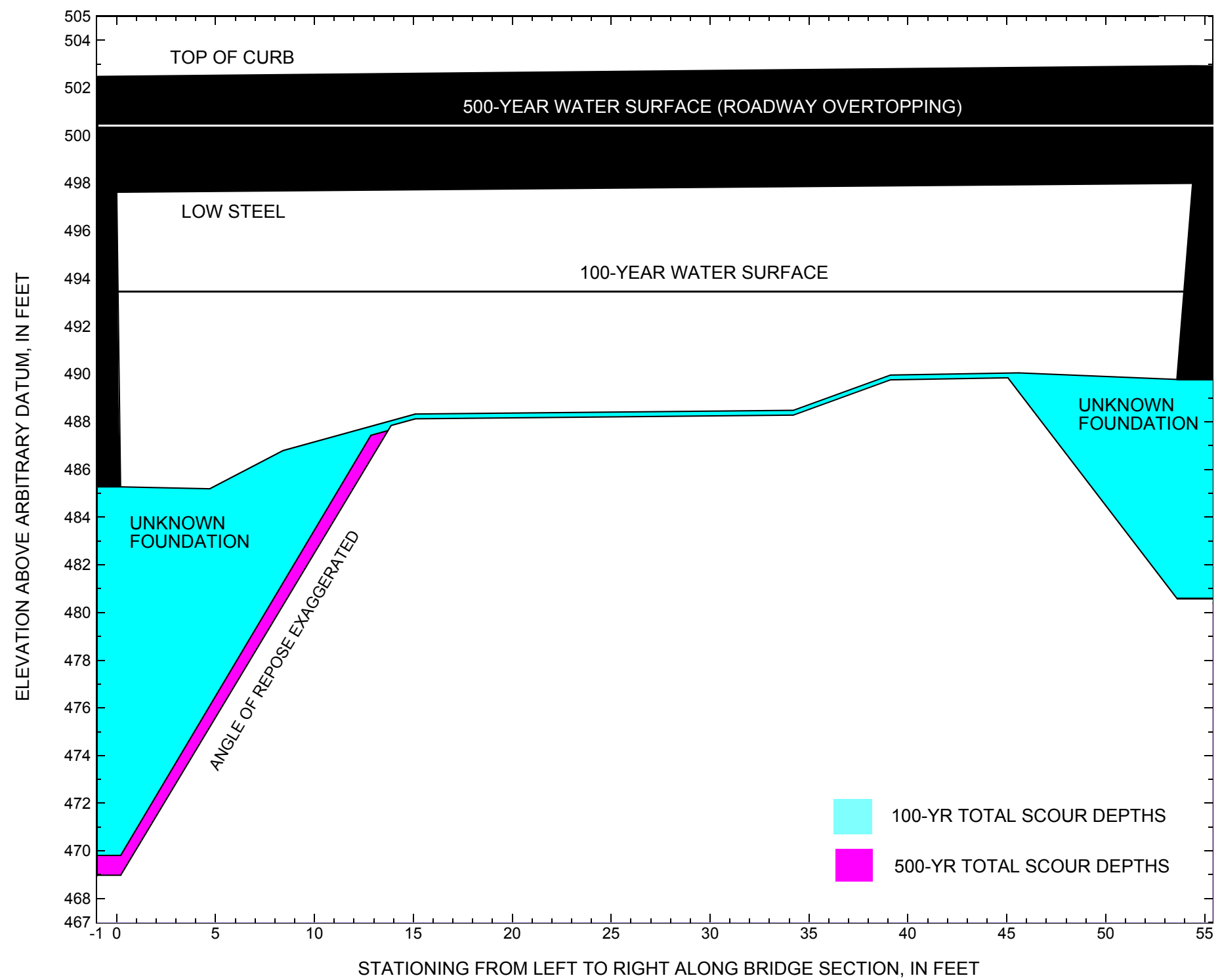

Figure 8. Scour elevations for the 100-yr and 500-yr discharges at structure REDSTH00360025 on Town Highway 36, crossing the West Branch Deerfield River, Readsboro, Vermont. 


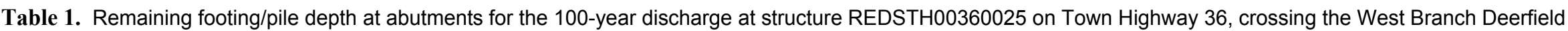
River, Readsboro, Vermont.

[VTAOT, Vermont Agency of Transportation; --,no data]

\begin{tabular}{|c|c|c|c|c|c|c|c|c|c|c|c|}
\hline Description & Station $^{1}$ & $\begin{array}{l}\text { VTAOT } \\
\text { minimum } \\
\text { low-chord } \\
\text { elevation } \\
\text { (feet) }\end{array}$ & $\begin{array}{l}\text { Surveyed } \\
\text { minimum } \\
\text { low-chord } \\
\text { elevation }{ }^{2} \\
\text { (feet) }\end{array}$ & $\begin{array}{c}\text { Bottom of } \\
\text { footing } \\
\text { elevation } \\
\text { (feet) }\end{array}$ & $\begin{array}{c}\text { Channel } \\
\text { elevation at } \\
\text { abutment/ } \\
\text { pier }^{2} \\
\text { (feet) }\end{array}$ & $\begin{array}{l}\text { Contraction } \\
\text { scour depth } \\
\text { (feet) }\end{array}$ & $\begin{array}{l}\text { Abutment } \\
\text { scour } \\
\text { depth } \\
\text { (feet) }\end{array}$ & $\begin{array}{l}\text { Pier } \\
\text { scour } \\
\text { depth } \\
\text { (feet) }\end{array}$ & $\begin{array}{l}\text { Depth of } \\
\text { total scour } \\
\text { (feet) }\end{array}$ & $\begin{array}{c}\text { Elevation of } \\
\text { scour }^{2} \\
\text { (feet) }\end{array}$ & $\begin{array}{c}\text { Remaining } \\
\text { footing/pile } \\
\text { depth } \\
\text { (feet) }\end{array}$ \\
\hline \multicolumn{12}{|c|}{100 -yr. discharge is 3,020 cubic-feet per second } \\
\hline Left abutment & 0.2 & - & 497.6 & - & 485.3 & 0.4 & 15.1 & -- & 15.5 & 469.8 & - \\
\hline Right abutment & 53.6 & - & 498.0 & - & 489.8 & 0.4 & 9.0 & -- & 9.4 & 480.4 & - \\
\hline
\end{tabular}

1.Measured along the face of the most constricting side of the bridge.

2.Arbitrary datum for this study.

Table 2. Remaining footing/pile depth at abutments for the 500-year discharge at structure REDSTH00360025 on Town Highway 36, crossing the West Branch Deerfield River, Readsboro, Vermont.

[VTAOT, Vermont Agency of Transportation; --, no data]

\begin{tabular}{|c|c|c|c|c|c|c|c|c|c|c|c|}
\hline Description & Station $^{1}$ & $\begin{array}{l}\text { VTAOT } \\
\text { minimum } \\
\text { low-chord } \\
\text { elevation } \\
\text { (feet) }\end{array}$ & $\begin{array}{c}\text { Surveyed } \\
\text { minimum } \\
\text { low-chord } \\
\text { elevation } \\
\text { (feet) }\end{array}$ & $\begin{array}{c}\text { Bottom of } \\
\text { footing } \\
\text { elevation } \\
\text { (feet) }\end{array}$ & $\begin{array}{c}\text { Channel } \\
\text { elevation at } \\
\text { abutment/ } \\
\text { pier }^{2} \\
\text { (feet) }\end{array}$ & $\begin{array}{l}\text { Contraction } \\
\text { scour depth } \\
\text { (feet) }\end{array}$ & $\begin{array}{l}\text { Abutment } \\
\text { scour } \\
\text { depth } \\
\text { (feet) }\end{array}$ & $\begin{array}{l}\text { Pier } \\
\text { scour } \\
\text { depth } \\
\text { (feet) }\end{array}$ & $\begin{array}{l}\text { Depth of } \\
\text { total scour } \\
\text { (feet) }\end{array}$ & $\begin{array}{c}\text { Elevation of } \\
\text { scour }^{2} \\
\text { (feet) }\end{array}$ & $\begin{array}{c}\text { Remaining } \\
\text { footing/pile } \\
\text { depth } \\
\text { (feet) }\end{array}$ \\
\hline \multicolumn{12}{|c|}{500 -yr. discharge is 4,750 cubic-feet per second } \\
\hline Left abutment & 0.2 & - & 497.6 & - & 485.3 & 0.0 & 16.3 & -- & 16.3 & 469.0 & - \\
\hline Right abutment & 53.6 & - & 498.0 & - & 489.8 & 0.0 & 9.2 & -- & 9.2 & 480.6 & - \\
\hline
\end{tabular}

1.Measured along the face of the most constricting side of the bridge.

2.Arbitrary datum for this study. 


\section{SELECTED REFERENCES}

Arcement, G.J., Jr., and Schneider, V.R., 1989, Guide for selecting Manning's roughness coefficients for natural channels and flood plains: U.S. Geological Survey Water-Supply Paper 2339, 38 p.

Barnes, H.H., Jr., 1967, Roughness characteristics of natural channels: U.S. Geological Survey Water-Supply Paper 1849,213 p.

Benson, M. A., 1962, Factors Influencing the Occurrence of Floods in a Humid Region of Diverse Terrain: U.S. Geological Survey WaterSupply Paper 1580-B, 64 p.

Brown, S.A. and Clyde, E.S., 1989, Design of riprap revetment: Federal Highway Administration Hydraulic Engineering Circular No. 11, Publication FHWA-IP-89-016, 156 p.

Federal Highway Administration, 1983, Runoff estimates for small watersheds and development of sound design: Federal Highway Administration Report FHWA-RD-77-158.

Federal Highway Administration, 1993, Stream Stability and Scour at Highway Bridges: Participant Workbook: Federal Highway Administration Report FHWA-HI-91-011.

Froehlich, D.C., 1989, Local scour at bridge abutments in Ports, M.A., ed., Hydraulic Engineering--Proceedings of the 1989 National Conference on Hydraulic Engineering: New York, American Society of Civil Engineers, p. 13-18.

Hayes, D.C.,1993, Site selection and collection of bridge-scour data in Delaware, Maryland, and Virginia: U.S. Geological Survey WaterResources Investigation Report 93-4017, 23 p.

Interagency Advisory Committee on Water Data, 1982, Guidelines for determining flood flow frequency: U.S. Geological Survey, Bulletin 17B of the Hydrology Subcommittee, 190 p.

Johnson, C.G. and Tasker, G.D.,1974, Progress report on flood magnitude and frequency of Vermont streams: U.S. Geological Survey OpenFile Report 74-130, 37 p.

Lagasse, P.F., Schall, J.D., Johnson, F., Richardson, E.V., Chang, F., 1995, Stream Stability at Highway Structures: Federal Highway Administration Hydraulic Engineering Circular No. 20, Publication FHWA-IP-90-014, 144 p.

Laursen, E.M., 1960, Scour at bridge crossings: Journal of the Hydraulics Division, American Society of Civil Engineers, v. 86, no. HY2, p. 39-53.

Potter, W. D., 1957a, Peak rates of runoff in the Adirondack, White Mountains, and Maine woods area, Bureau of Public Roads

Potter, W. D., 1957b, Peak rates of runoff in the New England Hill and Lowland area, Bureau of Public Roads

Richardson, E.V. and Davis, S.R., 1995, Evaluating scour at bridges: Federal Highway Administration Hydraulic Engineering Circular No. 18, Publication FHWA-IP-90-017, 204 p.

Richardson, E.V., Simons, D.B., and Julien, P.Y., 1990, Highways in the river environment: Federal Highway Administration Publication FHWA-HI-90-016.

Ritter, D.F., 1984, Process Geomorphology: W.C. Brown Co., Debuque, Iowa, 603 p.

Shearman, J.O., 1990, User's manual for WSPRO--a computer model for water surface profile computations: Federal Highway Administration Publication FHWA-IP-89-027, 187 p.

Shearman, J.O., Kirby, W.H., Schneider, V.R., and Flippo, H.N., 1986, Bridge waterways analysis model; research report: Federal Highway Administration Publication FHWA-RD-86-108, 112 p.

Talbot, A.N., 1887, The determination of water-way for bridges and culverts.

U.S. Department of Transportation, 1993, Stream stability and scour at highway bridges, Participant Workbook: Federal Highway Administration Publication FHWA HI-91-011.

U.S. Geological Survey, 1987, Readsboro, Vermont 7.5 Minute Series quadrangle map: U.S. Geological Survey Topographic Maps, Scale $1: 24,000$.

U.S. Geological Survey, 1954, Stamford, Vermont 7.5 Minute Series quadrangle map: U.S. Geological Survey Topographic Maps, Scale 1:24,000. 


\section{APPENDIX A: \\ WSPRO INPUT FILE}




\section{WSPRO INPUT FILE}

GR

GR

GR

GR

GR

*

$\mathrm{N}$

SA

*

$\mathrm{XS}$

BR

GR

GR

GR

GR

*

CD

$\mathrm{N}$

*

*

$\mathrm{XR}$

GR

GR

GR

$\mathrm{XT}$

GR

GR

GR

GR

GR

*

AS

GT

$\mathrm{N}$

SA

*

XS

GT

N

SA

*

XS

U.S. Geological Survey WSPRO Input File reds025.wsp

Hydraulic analysis for structure REDSTH00360025 Date: 07-MAR-97 Bridge \#25 over West Br. Deerfield River in Stamford, VT. RHF

* * 0.002

$\begin{array}{lllllllllllllllllllll}6 & 29 & 30 & 552 & 553 & 551 & 5 & 16 & 17 & 13 & 3 & * & 15 & 14 & 23 & 21 & 11 & 12 & 4 & 7 & 3\end{array}$

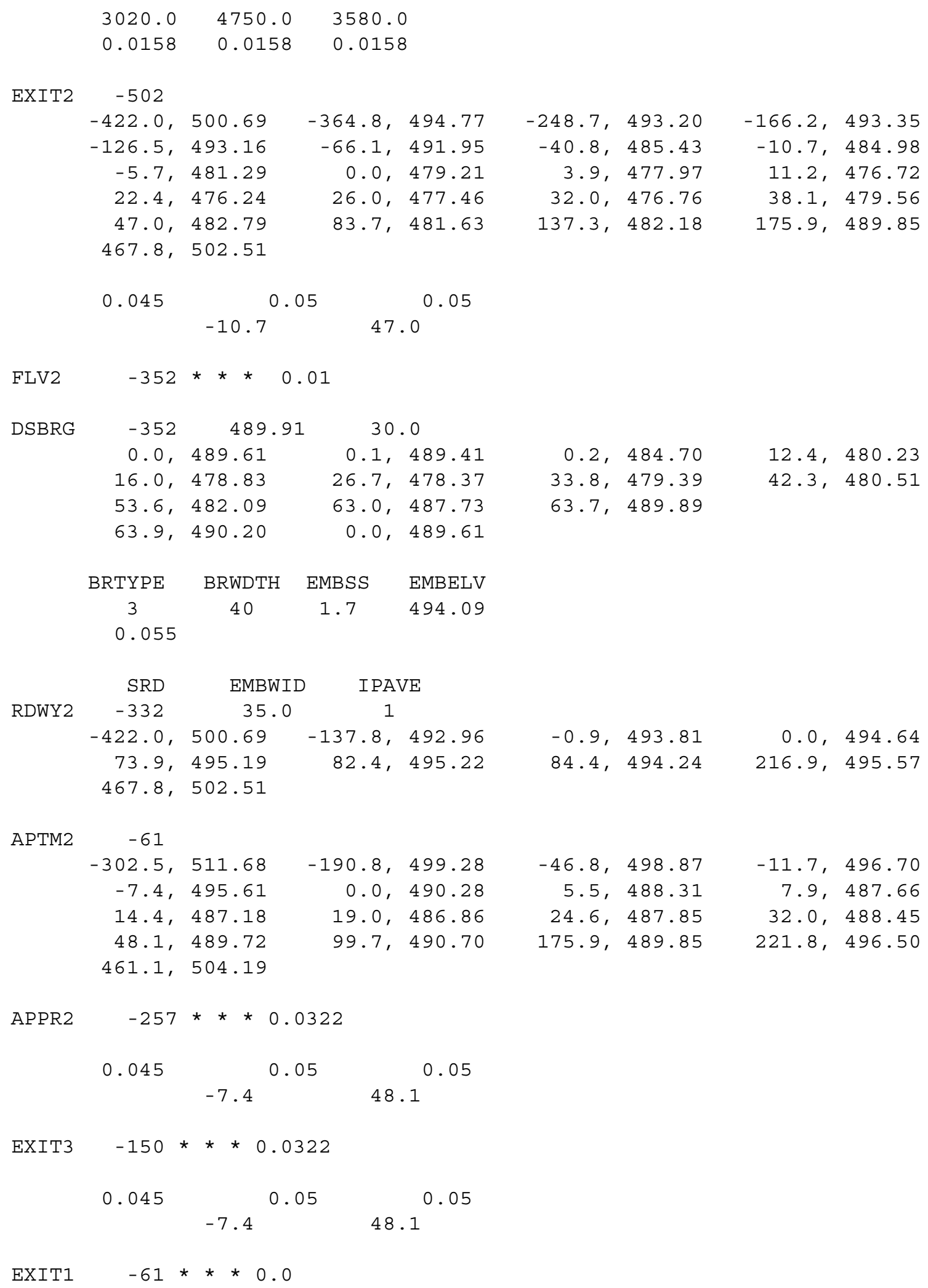




\section{WSPRO INPUT FILE (continued)}

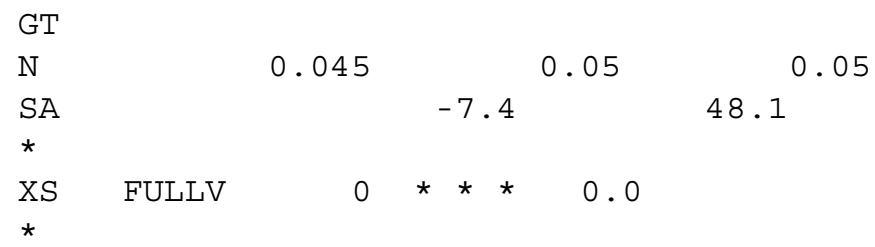

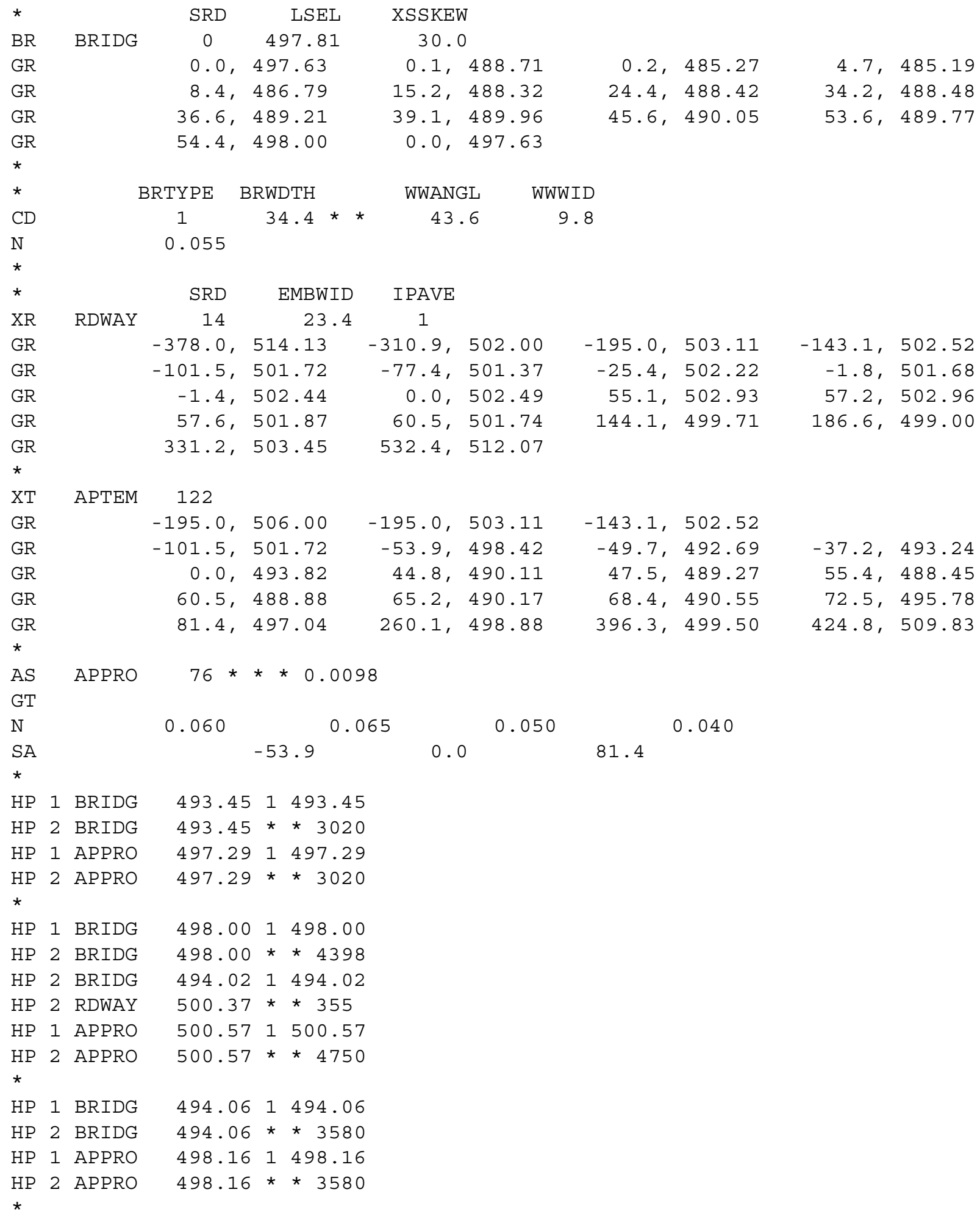




\section{APPENDIX B: \\ WSPRO OUTPUT FILE}


WSPRO OUTPUT FILE

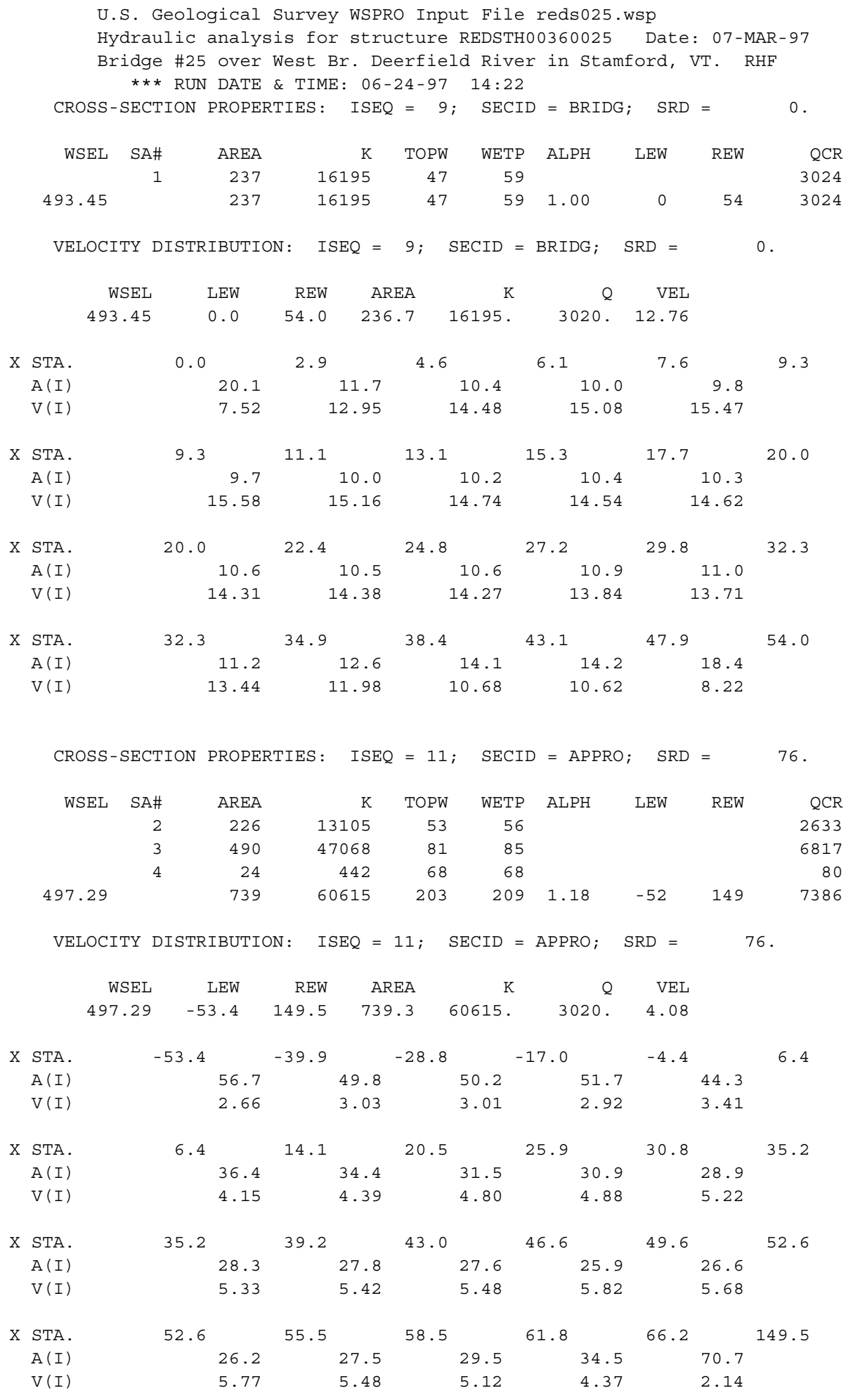




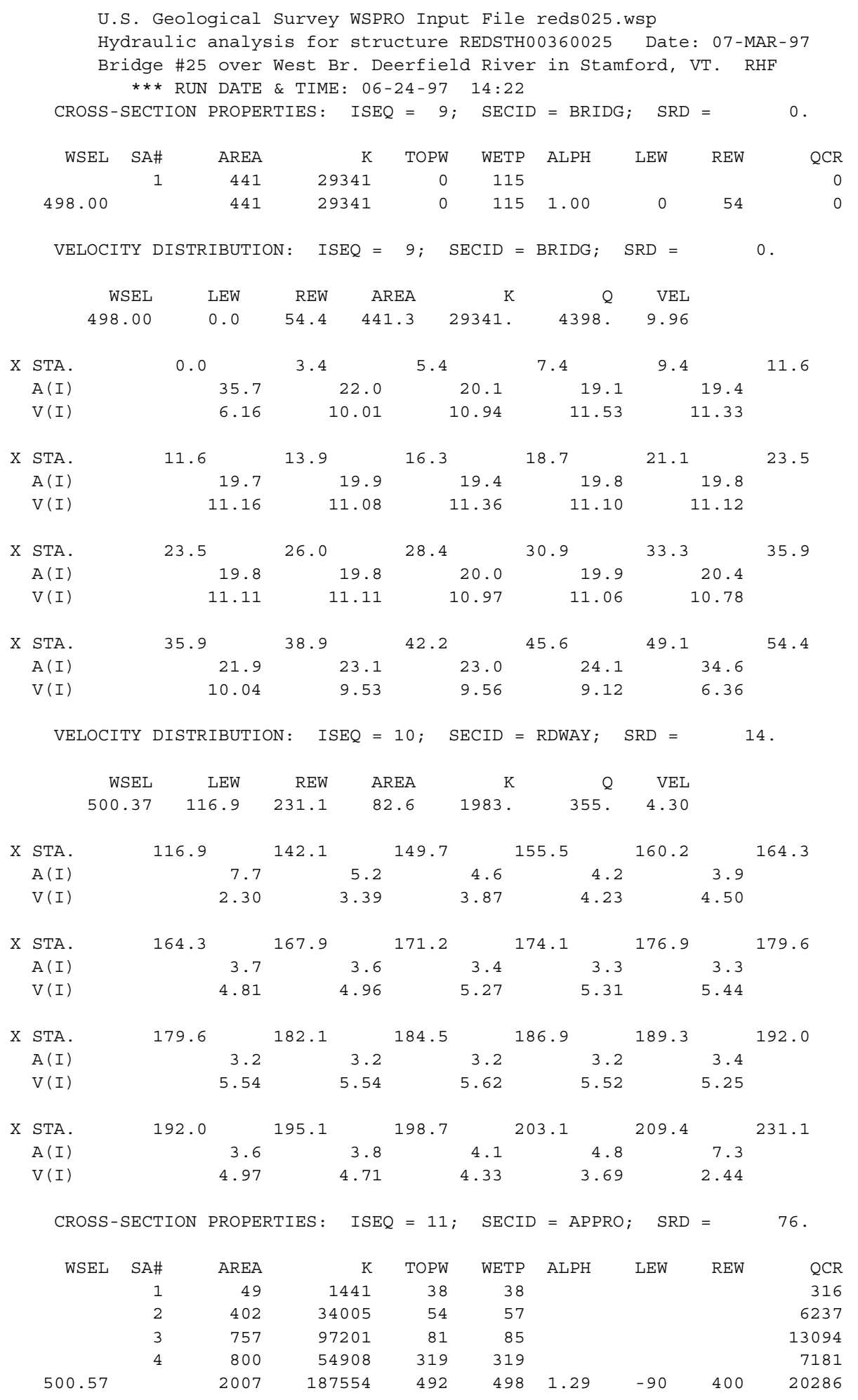


WSPRO OUTPUT FILE (continued)

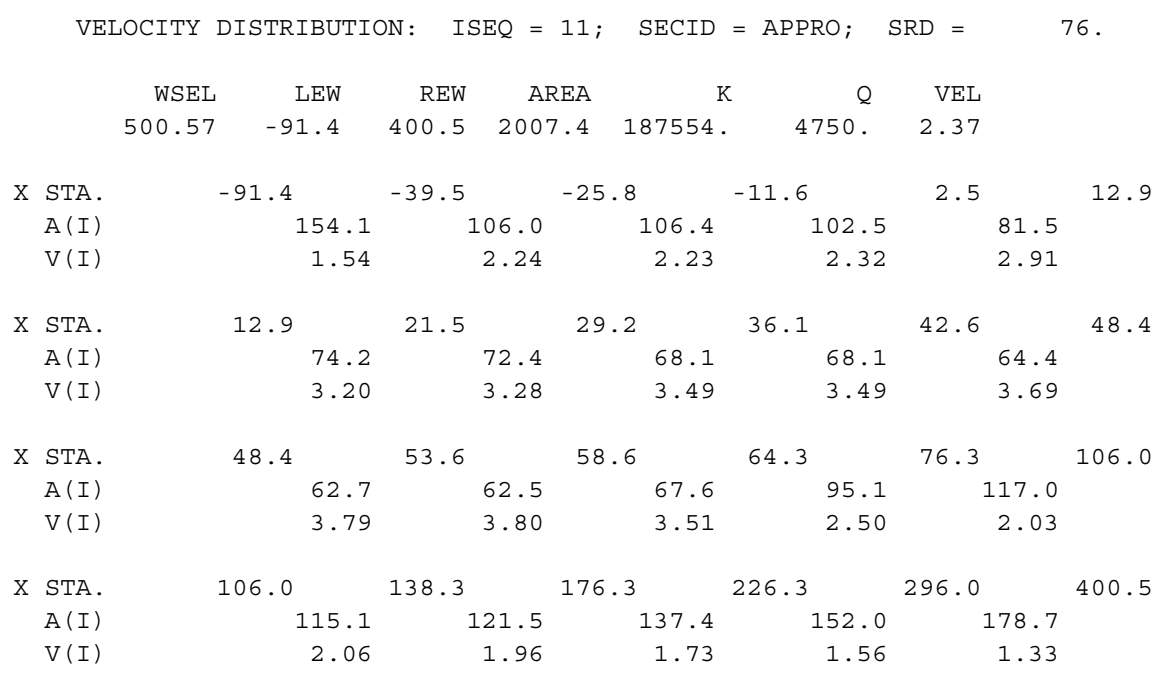

U.S. Geological Survey WSPRO Input File reds025.wsp Hydraulic analysis for structure REDSTH00360025 Date: 07-MAR-97 Bridge \#25 over West Br. Deerfield River in stamford, VT. RHF *** RUN DATE \& TIME: 06-24-97 14:22 CROSS-SECTION PROPERTIES: ISEQ $=9 ;$ SECID $=$ BRIDG; $\quad$ SRD $=0$.

$\begin{array}{rrrrrrrrrr}\text { WSEL } & \text { SA\# } & \text { AREA } & \text { K } & \text { TOPW } & \text { WETP } & \text { ALPH } & \text { LEW } & \text { REW } & \text { QCR } \\ & 1 & 265 & 19307 & 47 & 60 & & & & 3584 \\ 494.06 & & 265 & 19307 & 47 & 60 & 1.00 & 0 & 54 & 3584\end{array}$

VELOCITY DISTRIBUTION: $\quad$ ISEQ $=9 ; \quad$ SECID $=$ BRIDG $; \quad$ SRD $=\quad 0$.

\begin{tabular}{|c|c|c|c|c|c|c|c|c|c|c|c|}
\hline & & SEL & LEW & REW & ARE & & $\mathrm{K}$ & Q & VEL & & \\
\hline & 494 & .06 & 0.0 & 54.0 & 265 & & 307. & 3580 . & 13.50 & & \\
\hline $\mathrm{X}$ & STA. & 0.0 & & 3.1 & & 4.9 & & 6.5 & 8.2 & & 10.0 \\
\hline & $A(I)$ & & 23.2 & & 13.3 & & 1.7 & 11.3 & & 11.1 & \\
\hline & $V(I)$ & & 7.71 & & 13.43 & & .30 & 15.77 & & 16.17 & \\
\hline $\mathrm{X}$ & STA. & 10.0 & & 11.9 & & 14.0 & & 6.3 & 18.6 & & 20.9 \\
\hline & $A(I)$ & & 11.2 & & 11.5 & & 1.4 & 11.5 & & 11.5 & \\
\hline & $V(I)$ & & 16.00 & & 15.62 & & .67 & 15.55 & & 15.62 & \\
\hline $\mathrm{x}$ & STA. & 20.9 & & 23.3 & & 25.7 & & 8.1 & 30.6 & & 33.1 \\
\hline & $A(I)$ & & 11.7 & & 11.6 & & 1.7 & 12.1 & & 12.2 & \\
\hline & $V(I)$ & & 15.35 & & 15.42 & & .28 & 14.82 & & 14.67 & \\
\hline $\mathrm{X}$ & STA. & 33.1 & & 35.8 & & 39.4 & & $=3.6$ & 48.1 & & 54.0 \\
\hline & $A(I)$ & & 12.6 & & 14.2 & & 5.0 & 15.6 & & 20.8 & \\
\hline & $V(I)$ & & 14.26 & & 12.59 & & .95 & 11.49 & & 8.59 & \\
\hline & CROSS - & SECTION & PROPER & TIES : & ISEQ & $=11 ;$ & SECID & $=A P P R O$ & SRD & $=$ & 76. \\
\hline & WSEL & SA\# & AREA & & K & TOPW & WETP & ALPH & LEW & REW & QCR \\
\hline & & 1 & 0 & & 1 & 3 & 3 & & & & 0 \\
\hline & & 2 & 272 & & 7755 & 54 & 57 & & & & 3475 \\
\hline & & 3 & 561 & & 8949 & 81 & 85 & & & & 8348 \\
\hline & & 4 & 120 & & 3799 & 153 & 153 & & & & 603 \\
\hline & 498.16 & & 953 & & 0505 & 291 & 297 & 1.27 & -56 & 234 & 8681 \\
\hline
\end{tabular}

VELOCITY DISTRIBUTION: ISEQ $=11 ; \quad$ SECID $=$ APPRO $; \quad$ SRD = 76 .

\begin{tabular}{|c|c|c|c|c|c|c|c|c|}
\hline & WSEL & LEW & REW & AREA & I & $Q$ & VEL & \\
\hline & 498.16 & -56.7 & 234.0 & 953.1 & 80505 & 3580 . & 3.76 & \\
\hline X STA. & & -56.7 & -39.7 & -28.8 & & -17.3 & -5.3 & 5.6 \\
\hline$A(I)$ & & 70.0 & & 58.0 & 59.6 & 59.5 & & \\
\hline$V(I)$ & & 2.56 & & 3.08 & 3.00 & 3.01 & & \\
\hline
\end{tabular}


WSPRO OUTPUT FILE (continued)

\begin{tabular}{|c|c|c|c|c|c|c|c|}
\hline $\mathrm{X}$ & STA. & 5.6 & 13.3 & 19.9 & 25.7 & 30.9 & 35.6 \\
\hline & $A(I)$ & 43.1 & 40.8 & 38.4 & 37.0 & 35.6 & \\
\hline & $V(I)$ & 4.15 & 4.39 & 4.66 & 4.84 & 5.02 & \\
\hline $\mathrm{X}$ & STA. & 35.6 & 40.0 & 44.1 & 47.8 & 51.2 & 54.5 \\
\hline & $A(I)$ & 34.7 & 34.0 & 33.0 & 32.6 & 32.1 & \\
\hline & $V(I)$ & 5.16 & 5.26 & 5.43 & 5.48 & 5.58 & \\
\hline $\mathrm{X}$ & STA. & 54.5 & 57.7 & 61.2 & 65.6 & 79.0 & 234.0 \\
\hline & $A(I)$ & 33.1 & 34.4 & 38.7 & 60.9 & 124.0 & \\
\hline & $V(I)$ & 5.40 & 5.20 & 4.62 & 2.94 & 1.44 & \\
\hline
\end{tabular}

U.S. Geological Survey WSPRO Input File reds025.wsp Hydraulic analysis for structure REDSTH00360025 Date: 07-MAR-97 Bridge \#25 over West Br. Deerfield River in Stamford, VT. RHF *** RUN DATE \& TIME: 06-24-97 14:22

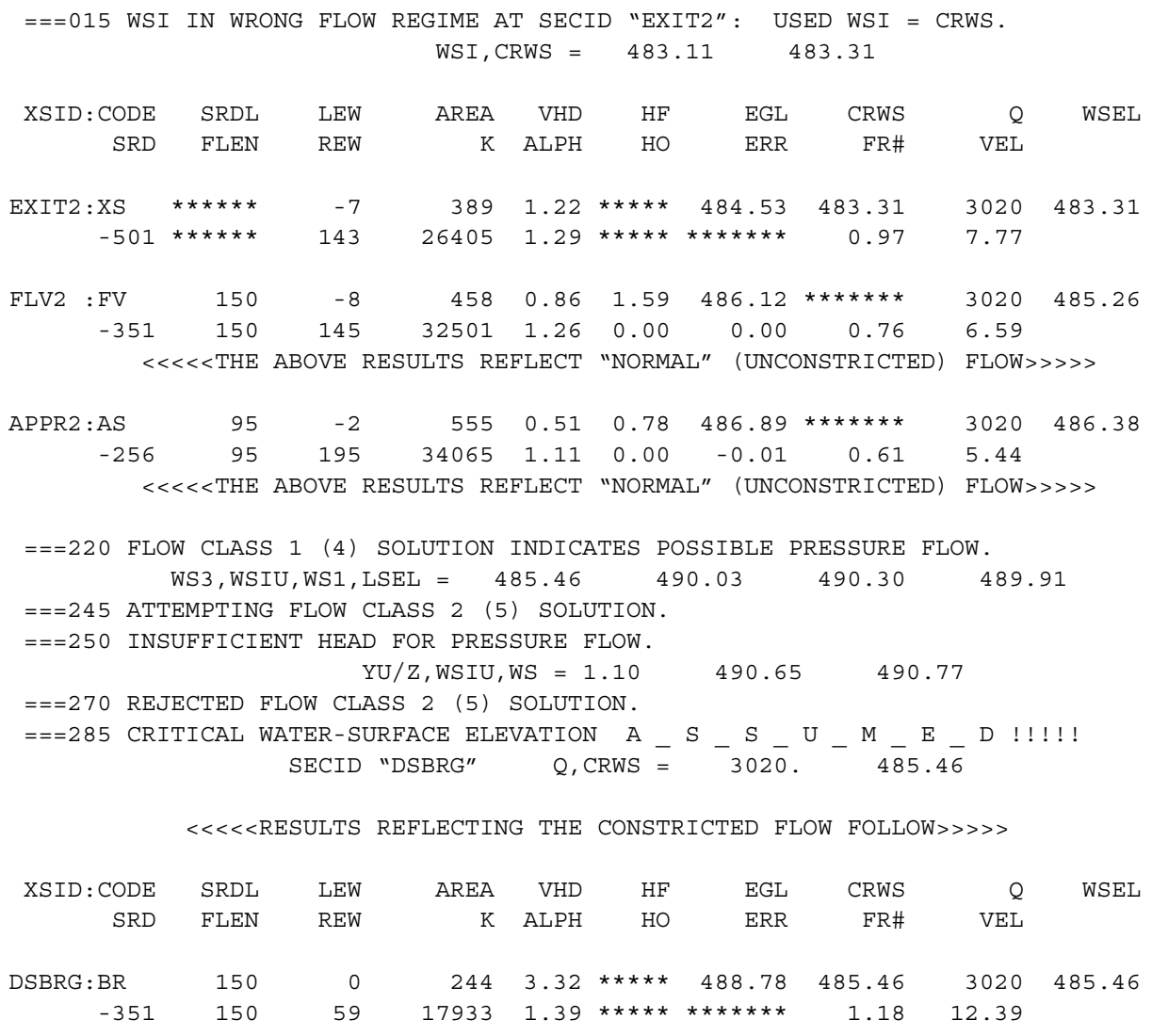


WSPRO OUTPUT FILE (continued)

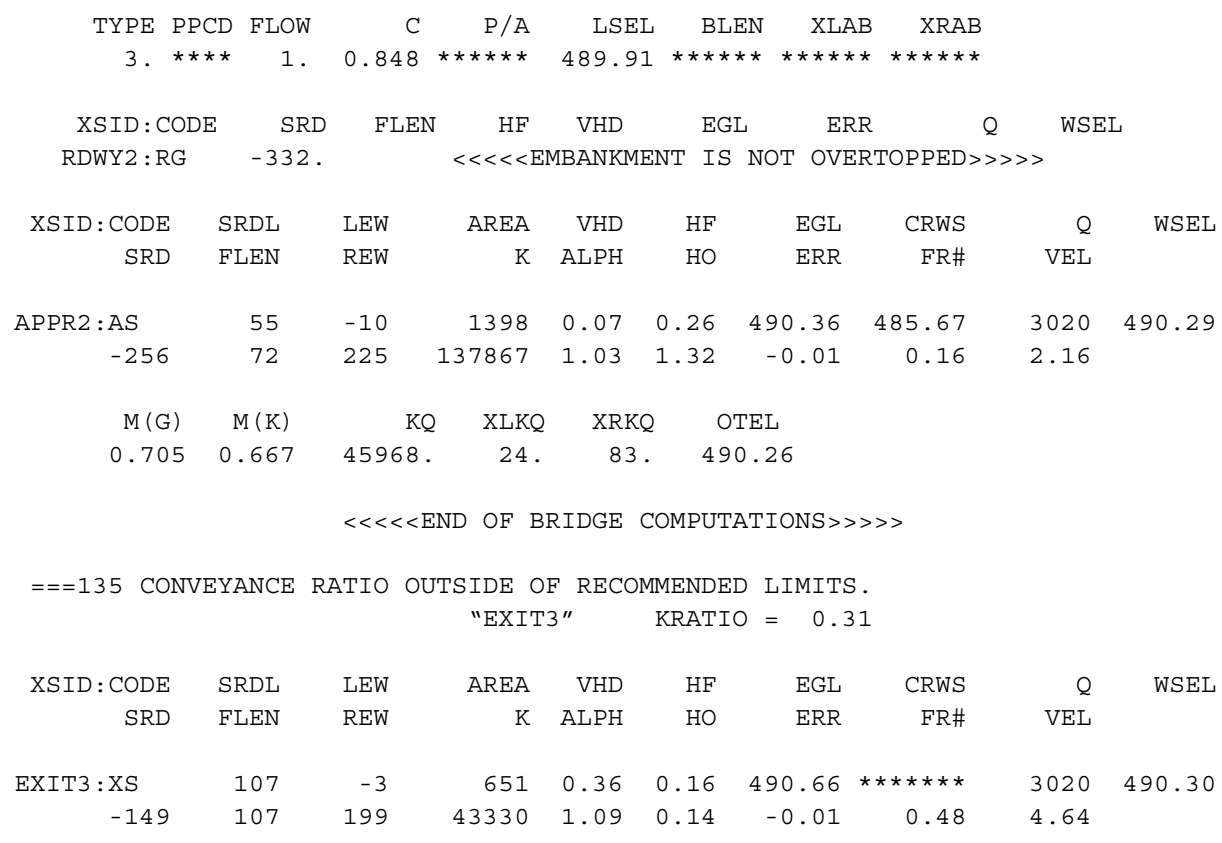

$==110$ WSEL NOT FOUND AT SECID "EXIT1": REDUCED DELTAY .

WSLIM1, WSLIM2, DELTAY $=489.80 \quad 511.68 \quad 0.50$

$===115$ WSEL NOT FOUND AT SECID "EXIT1": USED WSMIN = CRWS.

WSLIM1, WSLIM2, CRWS $=489.80 \quad 511.68 \quad 491.98$

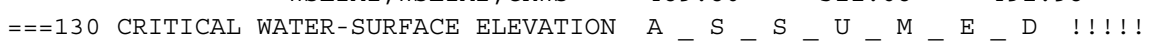

ENERGY EQUATION N_O_T B_A_L_A_N_C_E_D AT SECID "EXIT1" WSBEG, WSEND, $\bar{C} \bar{R} W \bar{S}=4 \overline{91} .9 \overline{8}-\overline{5} 11.68 \quad 491.98$

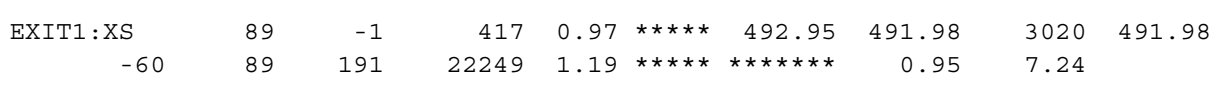

$==135$ CONVEYANCE RATIO OUTSIDE OF RECOMMENDED LIMITS .

"FULLV" KRATIO $=1.94$

$\begin{array}{rrrrrrrrrr}\text { FULLV : FV } & 61 & -3 & 650 & 0.36 & 0.58 & 493.52 & * \star * * * * * & 3020 & 493.16 \\ & 0 & 61 & 199 & 43198 & 1.09 & 0.00 & -0.01 & 0.48 & 4.65\end{array}$

$<<<<$ THE ABOVE RESULTS REFLECT "NORMAL" (UNCONSTRICTED) FLOW >>>>

$===110$ WSEL NOT FOUND AT SECID "APPRO": REDUCED DELTAY.

WSLIM1, WSLIM2, DELTAY $=492.66 \quad 509.38 \quad 0.50$

$==115$ WSEL NOT FOUND AT SECID "APPRO": USED WSMIN = CRWS.

WSLIM1,WSLIM2, CRWS $=492.66 \quad 509.38 \quad 494.45$

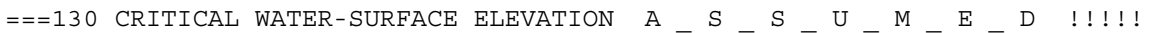

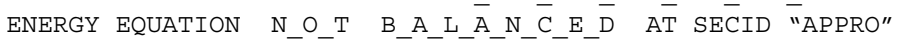
WSBEG, WSEND, CRWS $=494.45 \quad 509.38 \quad 494.45$

U.S. Geological Survey WSPRO Input File reds025.wsp

Hydraulic analysis for structure REDSTH00360025 Date: 07-MAR-97

Bridge \#25 over West Br. Deerfield River in Stamford, VT. RHF

*** RUN DATE \& TIME: 06-24-97 14:22

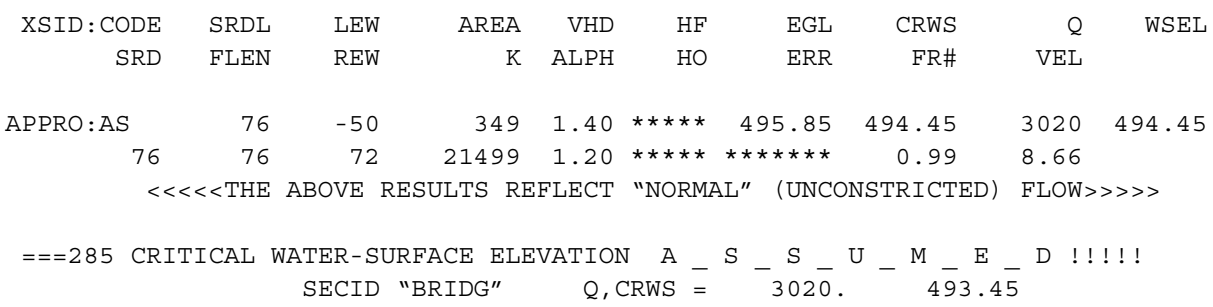


WSPRO OUTPUT FILE (continued)

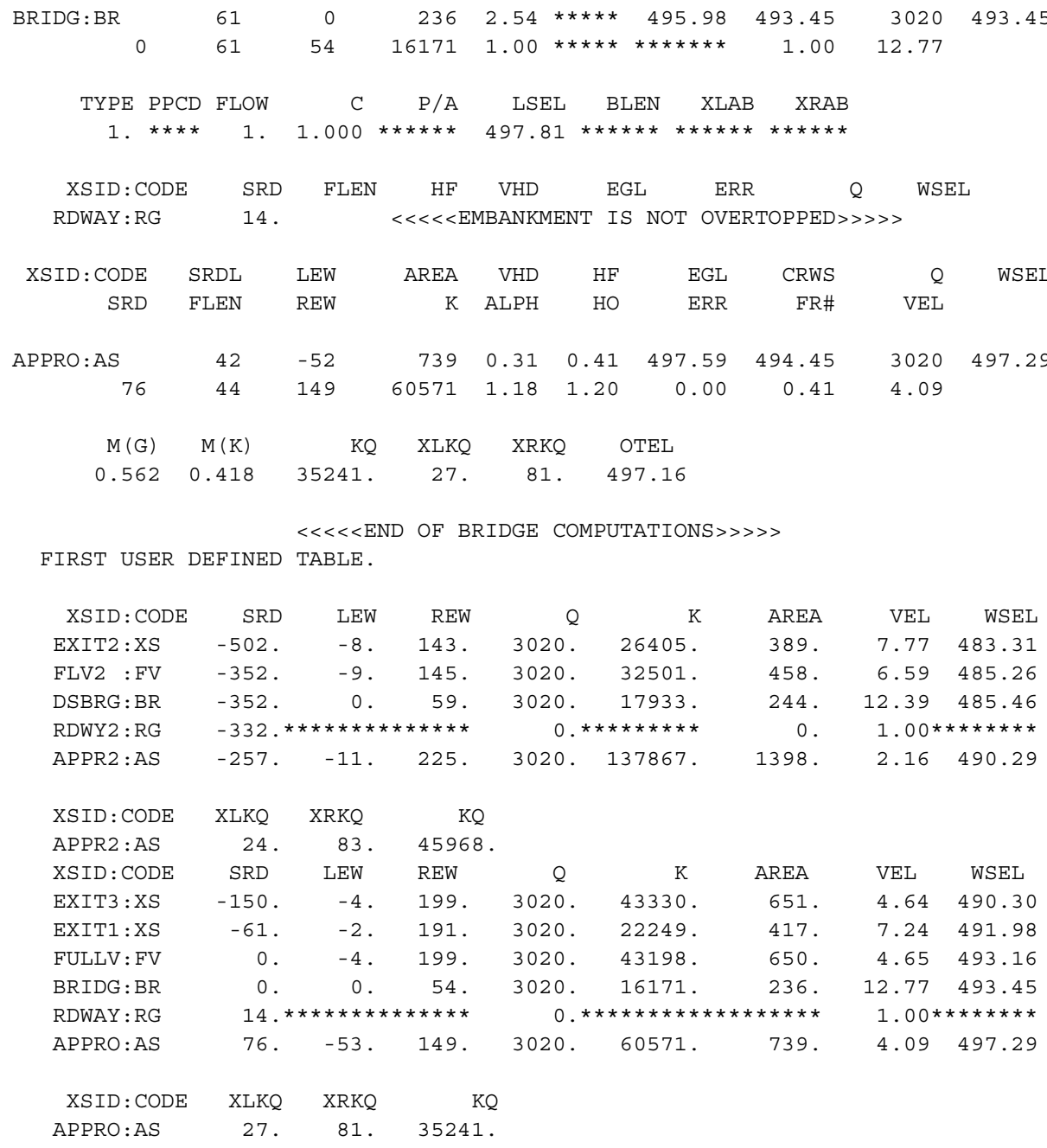

SECOND USER DEFINED TABLE.

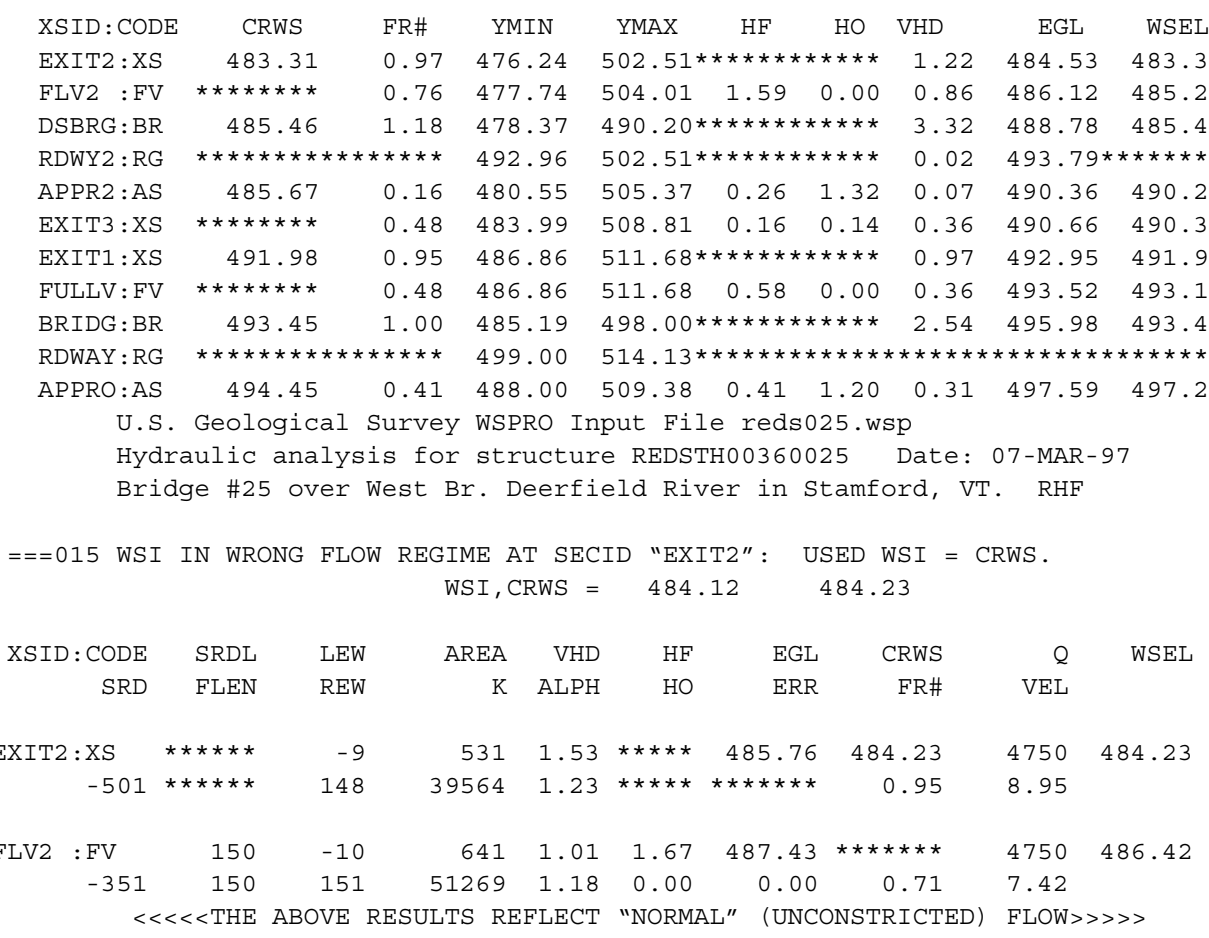


WSPRO OUTPUT FILE (continued)

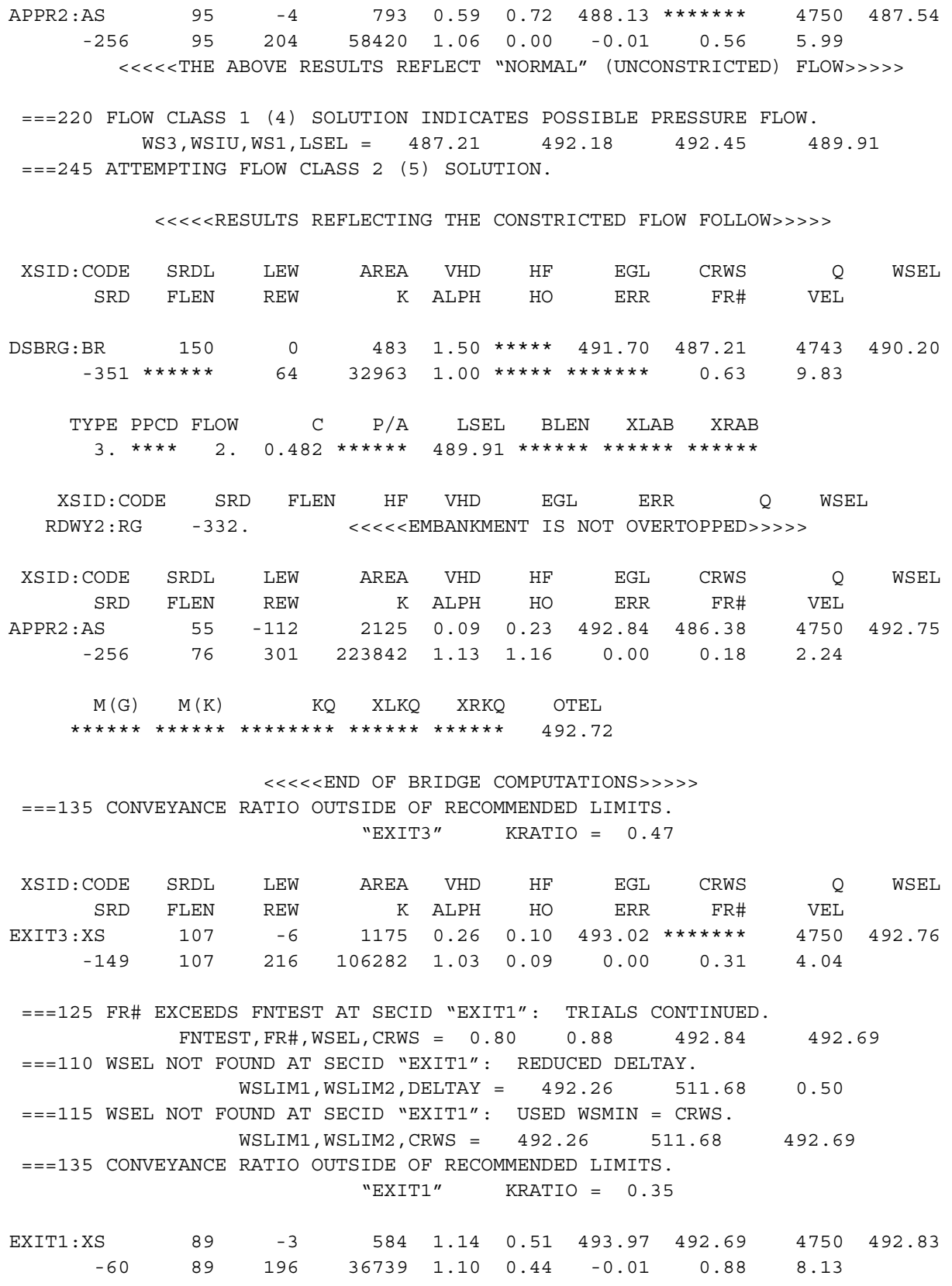


WSPRO OUTPUT FILE (continued)

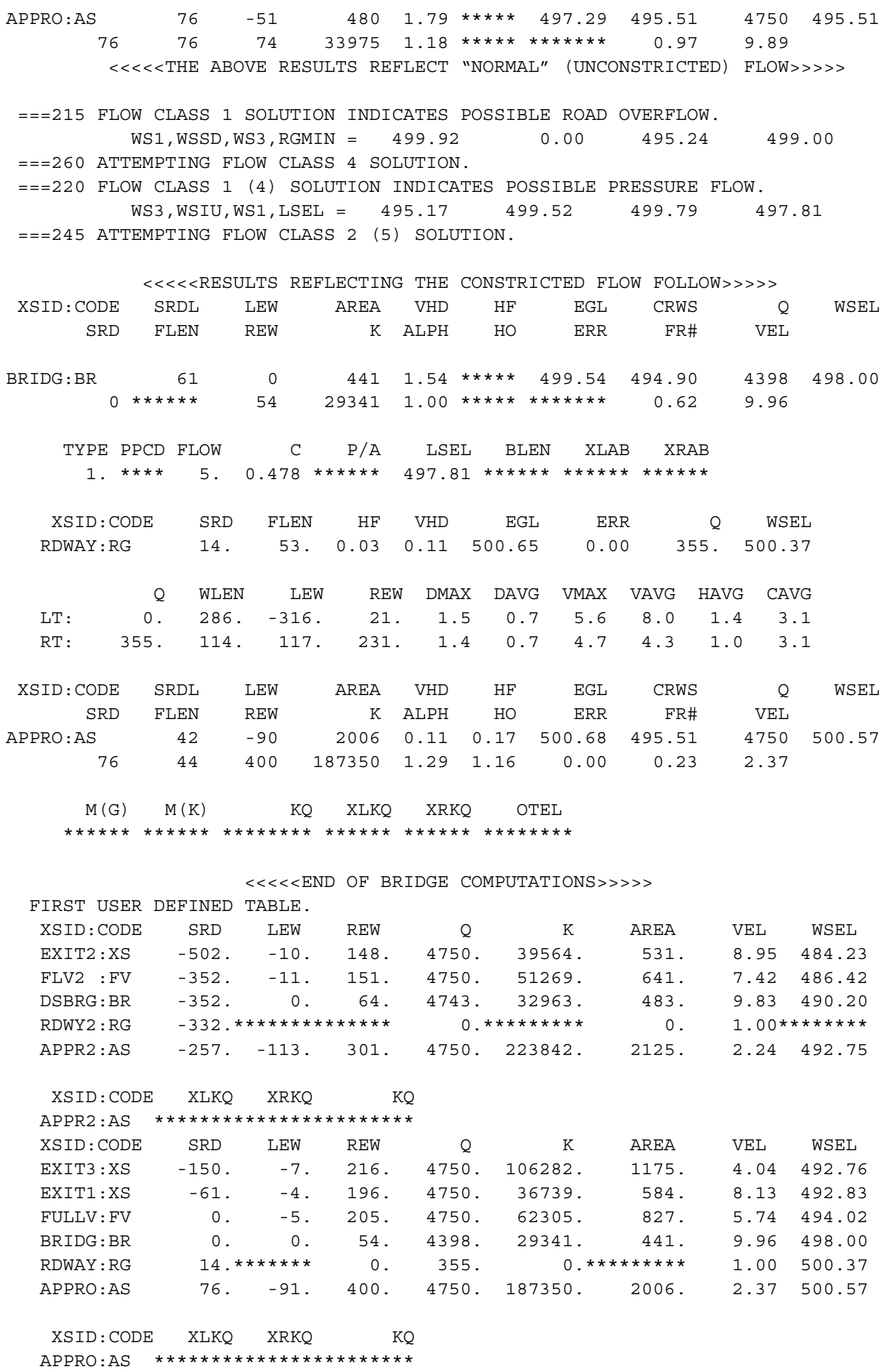

SECOND USER DEFINED TABLE.

\begin{tabular}{|c|c|c|c|c|c|c|c|c|c|}
\hline $\mathrm{XSID}: \mathrm{CODE}$ & CRWS & FR\# & YMIN & YMAX & $\mathrm{HF}$ & $\mathrm{HO}$ & VHD & EGL & WSEL \\
\hline EXIT2:XS & 484.23 & .95 & 476.24 & \multicolumn{3}{|c|}{$502.51 * * * * * * * * * * * *$} & 1.53 & 485.76 & 84.23 \\
\hline FLV2 :FV & 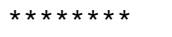 & 0.71 & 477.74 & 504.01 & 1.67 & 0.00 & 1.01 & 487.43 & 486.42 \\
\hline DSBRG : BR & 487.21 & 0.63 & 478.37 & \multicolumn{3}{|c|}{$490.20 * * * * * * * * * * * *$} & 1.50 & 491.70 & 490.20 \\
\hline RDWY2 : RG & \multicolumn{2}{|c|}{ 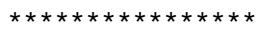 } & 492.96 & \multicolumn{3}{|c|}{$502.51 * * * \star * \star * * * * * * *$} & 0.06 & \multicolumn{2}{|c|}{ 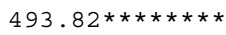 } \\
\hline APPR2 : AS & 486.38 & .18 & 480.55 & 505.37 & 23 & 1.16 & 0.09 & 492.84 & 92.75 \\
\hline EXIT3:XS & $* * *$ & 0.31 & 483.99 & 508.81 & 0.10 & 09 & 0.26 & .02 & 492.76 \\
\hline EXIT1:XS & 492.69 & 0.88 & 486.86 & 511.68 & 0.51 & 0.44 & 1.14 & 3.97 & 492.83 \\
\hline FULLV : FV & $\star \star \star \star ~$ & 0.52 & 486.86 & 511.68 & 0.60 & 0.00 & 0.54 & .56 & 94.02 \\
\hline BRIDG : BR & 494.90 & 0.62 & 485.19 & \multicolumn{3}{|c|}{$498.00 * * * * * * * * * * * *$} & 1.54 & 499.54 & 498.00 \\
\hline RDWA & 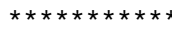 & $\star \star \star \star ~ *$ & 499.00 & 514.13 & 0.03 & 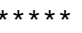 & 0.11 & 500.65 & 500.37 \\
\hline
\end{tabular}




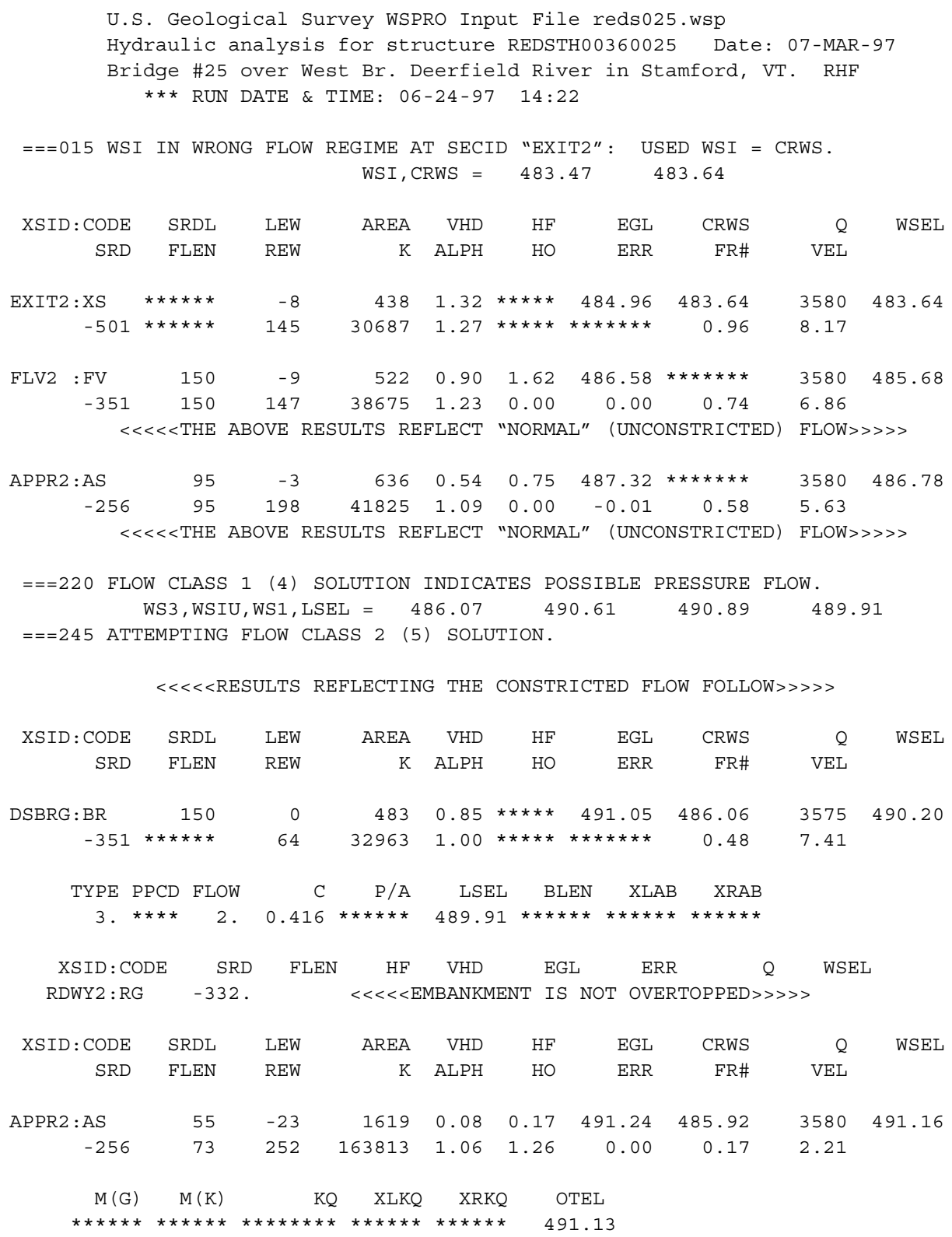




\section{APPENDIX C:}

\section{BED-MATERIAL PARTICLE-SIZE DISTRIBUTION}




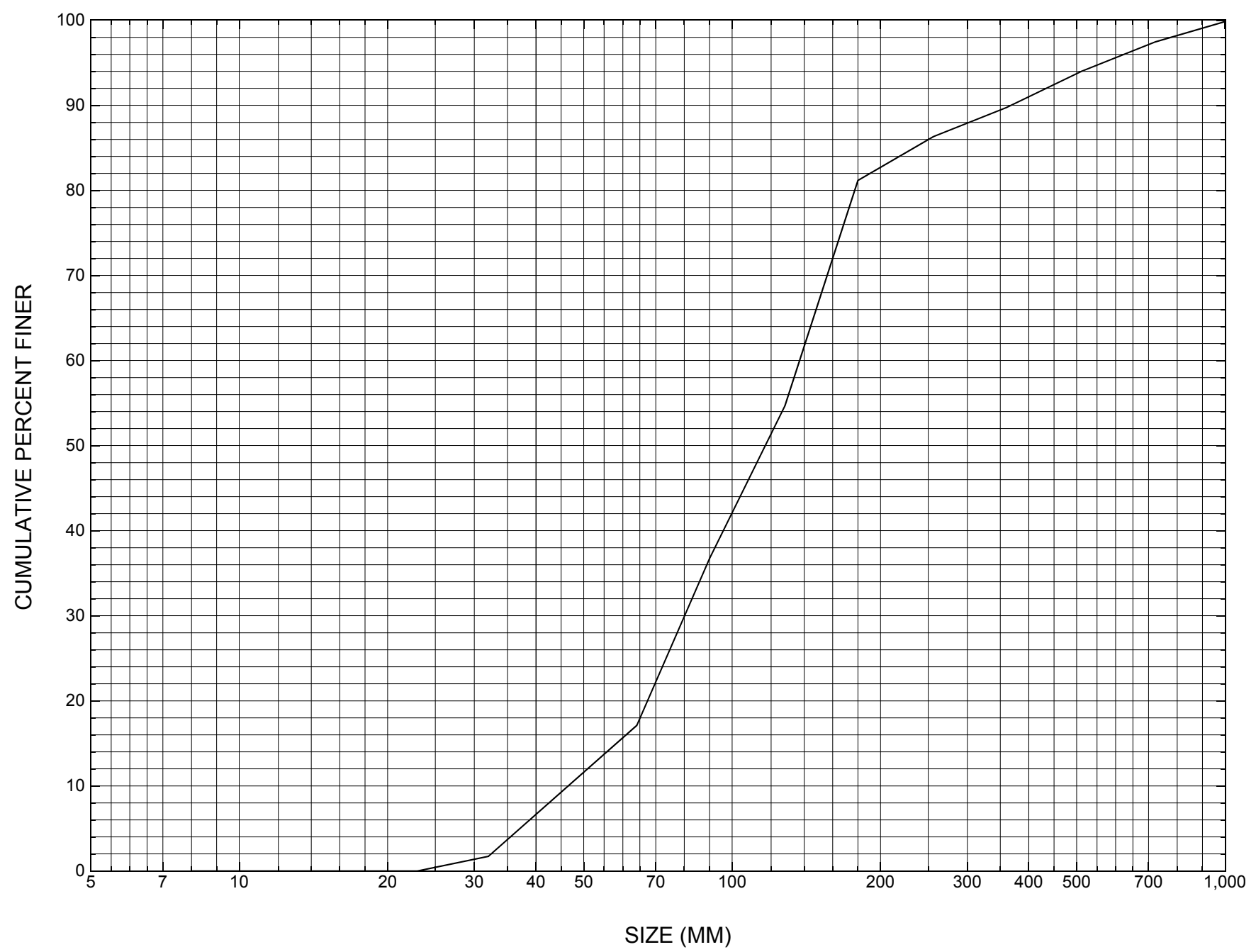

Appendix C. Bed material particle-size distribution for a pebble count in the channel approach of structure REDSTH00360025, in Readsboro, Vermont. 


\section{APPENDIX D: \\ HISTORICAL DATA FORM}




\section{Structure Number REDSTH00360025}

\section{General Location Descriptive}

Data collected by (First Initial, Full last name) $\underline{\mathbf{L}}$. Medalie

Date $(M M / D D / Y Y) \_09 / \underline{28} / \underline{95}$

Highway District Number $(I-2 ; n n) \underline{01}$

Town (FIPS place code; I - 4; nnnnn) $\mathbf{5 8 6 0 0}$

Waterway (I - 6) West Branch Deerfield River

Route Number $\mathbf{C 3 0 3 6}$

Topographic Map Stamford

Latitude (I - 16; nnnn.n) $\mathbf{4 2 4 9 6}$
County (FIPS county code; I - 3; nnn)

Mile marker (I - 11; nnn.nnn) $\underline{\mathbf{0 0 0 0 0 0}}$

Road Name (I - 7): -

Vicinity (I - 9) $\mathbf{0 . 1 1}$ mi. to jet. with VT100

Hydrologic Unit Code: $\underline{\mathbf{0 2 0 2 0 0 0 3}}$

Longitude (i - 17; nnnnn.n) $\mathbf{7 3 0 0 2}$

\section{Select Federal Inventory Codes}

FHWA Structure Number $(I$ - 8) 10020900250209

Maintenance responsibility $(I-21 ; n n) \quad \mathbf{0 3} \quad$ Maximum span length $(I-48 ; n n n n) \underline{\mathbf{0 0 5 7}}$

Year built (I - 27; YYYY) 1929

Structure length (I - 49; nnnnnn) $\underline{\mathbf{0 0 0 0 5 9}}$

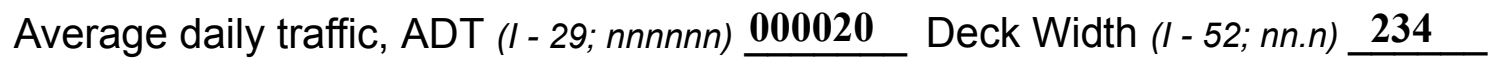

Year of ADT (I - 30; YY) $\mathbf{9 3}$

Channel \& Protection $(I-61 ; n) \underline{5}$

Opening skew to Roadway $(I-34 ; n n) \quad \mathbf{3 0}$

Waterway adequacy $(I-71 ; n) \underline{7}$

Operational status $(I-41 ; X)$ A

Underwater Inspection Frequency $(I-92 B ; X Y Y) \_\mathbf{N}$

Structure type (I - 43; nnn) 104

Year Reconstructed (I - 106) $\mathbf{0 0 0 0}$

Approach span structure type (I - 44; nnn) $\mathbf{0 0 0}$

Clear span (nnn.n ft) _ _

Number of spans (I - 45; nnn) $\underline{\mathbf{0 0 1}}$

Vertical clearance from streambed (nnn.n ft) -

Number of approach spans (I - 46; nnnn) $\mathbf{0 0 0 0}$

Waterway of full opening $\left(n n n . n \mathrm{ft}^{2}\right)$

Comments:

According to the structural inspection report dated 9/27/93, the structure is a concrete T-beam bridge with an asphalt road surface. Abutments, wingwalls and backwalls are concrete. The left abutment con crete has several fine vertical cracks with alligator cracks and leaks on the ends of both abutments and wingwalls. The ends of both wingwalls on the left abutment have areas of deep spalling. The channel flow is along the upstream end and wingwall of the right abutment, and is diverted against the face of the left abutment. The channel is at least 2.5-3' deep along the upstream right abutment and 1.5-2.5' deep along the left abutment. A few boulders are present in front of the downstream right (Continued, p. 37) 


\section{Bridge Hydrologic Data}

Is there hydrologic data available? $\underline{\mathbf{N}}$ if No, type ctrl- $n$ VTAOT Drainage area $\left(m i^{2}\right)$ :

Terrain character:

Stream character \& type: -

Streambed material: boulders

Discharge Data (cfs): $\quad \mathrm{Q}_{2.33}-$

$$
\mathrm{Q}_{50}-
$$

Record flood date $(M M / D D / Y Y):-$

$\begin{array}{ll}Q_{10}- & Q_{25}- \\ Q_{100 \_-} & Q_{500}-\end{array}$

Water surface elevation (ft): -

Estimated Discharge (cfs): Velocity at $\mathrm{Q}-$ $(\mathrm{ft} / \mathrm{s}):$

Ice conditions (Heavy, Moderate, Light) : -

Debris (Heavy, Moderate, Light):

The stage increases to maximum highwater elevation (Rapidly, Not rapidly):

The stream response is (Flashy, Not flashy):

Describe any significant site conditions upstream or downstream that may influence the stream's stage: -

Watershed storage area (in percent): - $\%$

The watershed storage area is: - _ (1-mainly at the headwaters; 2- uniformly distributed; 3-immediatly upstream oi the site)

Water Surface Elevation Estimates for Existing Structure:

\begin{tabular}{|l|l|l|l|l|l|}
\hline Peak discharge frequency & $Q_{2.33}$ & $Q_{10}$ & $Q_{25}$ & $Q_{50}$ & $Q_{100}$ \\
Water surface elevation (ft)) & - & - & - & - & - \\
Velocity $(\mathrm{ft} / \mathrm{sec})$ & - & - & - & - & - \\
\hline
\end{tabular}

Long term stream bed changes: -

Is the roadway overtopped below the $Q_{100}$ ? (Yes, No, Unknown):

Frequency: -

Relief Elevation $(f t)$ :

Discharge over roadway at $Q_{100}\left(f^{3} / \mathrm{sec}\right)$ :

Are there other structures nearby? (Yes, No, Unknown): If No or Unknown, type ctrl-n os Upstream distance (miles): Town: Year Built:

Highway No. : Structure No. : -

Clear span $(f t)$ : Clear Height (ft): Full Waterway $\left(f t^{2}\right)$ : 
Downstream distance (miles): Town: Year Built:

Highway No. : Structure No. : Structure Type:

Clear span $(f t):$ Clear Height $(f t)$ : Full Waterway $\left(f t^{2}\right)$ :

Comments:

abutment, with boulders showing at the ends of the wingwalls and along the channel embankments. Minor debris and poor channel alignment were noted in the VT AOT files. No undermining or footing seen. There is a remark in the report that "water is quite swift and deep - hard to check for undermining".

\section{USGS Watershed Data}

Watershed Hydrographic Data Drainage area $(D A) \underline{14.45} \mathrm{mi}^{2}$

Watershed storage (ST) 6.24

Bridge site elevation 1808

Main channel length 5.16 Lake/pond/swamp area 0.901 $\mathrm{mi}^{2}$ $10 \%$ channel length elevation 1940

Main channel slope (S) 73.03 $\mathrm{ft} / \mathrm{mi}$ $\%$ Headwater elevation $\quad 3064 \quad \mathrm{ft}$ mi

Watershed Precipitation Data

Average site precipitation in Average headwater precipitation in

Maximum 2yr-24hr precipitation event $(124,2)$ in

Average seasonal snowfall (Sn) $\mathrm{ft}$ 


\section{Bridge Plan Data}

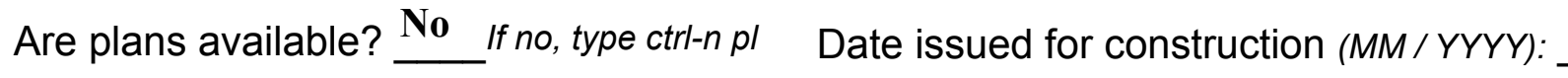
Project Number Minimum channel bed elevation:

Low superstructure elevation: USLAB DSLAB USRAB DSRAB Benchmark location description:

No benchmark information is available.

Reference Point (MSL, Arbitrary, Other): Datum (NAD27, NAD83, Other):

Foundation Type: 4

If 1: Footing Thickness

If 2: Pile Type: (1-Wood; 2-Steel or metal; 3-Concrete)

If 3: Footing bottom elevation:

Is boring information available? Foundation Material Type: 3 (1-Spreadfooting; 2-Pile; 3- Gravity; 4-Unknown) Footing bottom elevation: -

Briefly describe material at foundation bottom elevation or around piles:

No foundation material information is available.

Comments:

$-$ 


\section{Cross-sectional Data}

Is cross-sectional data available? $\underline{\mathbf{Y}}$

If no, type ctrl-n xs

Source (FEMA, VTAOT, Other)? VTAOT

This cross section is along the upstream face. The low chord elevations are from the survey

Comments: log completed for this report on 8/1/96. The low chord to bed length data are from the sketch attached to a bridge inspection report dated 9/27/93.

\begin{tabular}{|l|l|l|l|l|l|l|l|l|l|l|l|}
\hline Station & $\mathbf{0}$ & $\mathbf{2 6}$ & $\mathbf{3 9}$ & $\mathbf{5 4}$ & - & - & - & - & - & - \\
\hline Feature & LAB & & & RAB & - & - & - & - & - & - & - \\
\hline $\begin{array}{l}\text { Low cord } \\
\text { elevation }\end{array}$ & $\mathbf{4 9 7 . 6}$ & $\mathbf{4 9 7 . 8}$ & $\mathbf{4 9 7 . 9}$ & $\mathbf{4 9 8 . 0}$ & - & - & - & - & - & - & - \\
\hline $\begin{array}{l}\text { Bed } \\
\text { elevation }\end{array}$ & $\mathbf{4 8 7 . 4}$ & $\mathbf{4 8 8 . 2}$ & $\mathbf{4 8 7 . 0}$ & $\mathbf{4 8 7 . 5}$ & - & - & - & - & - & - & - \\
\hline $\begin{array}{l}\text { Low cord to } \\
\text { bed length }\end{array}$ & $\mathbf{1 0 . 2}$ & $\mathbf{9 . 6}$ & $\mathbf{1 0 . 9}$ & $\mathbf{1 0 . 5}$ & - & - & - & - & - & - & - \\
\hline \begin{tabular}{l} 
Station \\
\hline
\end{tabular} & - & - & - & - & - & - & - & - & - & - & - \\
\hline $\begin{array}{l}\text { Feature } \\
\text { Featur } \\
\text { elevation }\end{array}$ & - & - & - & - & - & - & - & - & - & - \\
\hline $\begin{array}{l}\text { Bed } \\
\text { elevation }\end{array}$ & - & - & - & - & - & - & - & - & - & - \\
\hline $\begin{array}{l}\text { Low cord to } \\
\text { bed length }\end{array}$ & - & - & - & - & - & - & - & - & - & - \\
\hline
\end{tabular}

Source (FEMA, VTAOT, Other)?

Comments: -

\begin{tabular}{|c|c|c|c|c|c|c|c|c|c|c|c|}
\hline Station & - & - & - & - & - & - & - & - & - & - & - \\
\hline Feature & - & - & - & - & - & - & - & - & - & - & - \\
\hline $\begin{array}{l}\text { Low cord } \\
\text { elevation }\end{array}$ & - & - & - & - & - & - & - & - & - & - & - \\
\hline $\begin{array}{l}\text { Bed } \\
\text { elevation }\end{array}$ & - & - & - & - & - & - & - & - & - & - & - \\
\hline $\begin{array}{l}\text { Low cord to } \\
\text { bed length }\end{array}$ & - & - & - & - & - & - & - & - & - & - & - \\
\hline Station & - & - & - & - & - & - & - & - & - & - & - \\
\hline Feature & - & - & - & - & - & - & - & - & - & - & - \\
\hline $\begin{array}{l}\text { Low cord } \\
\text { elevation }\end{array}$ & - & - & - & - & - & - & - & - & - & - & - \\
\hline $\begin{array}{l}\text { Bed } \\
\text { elevation }\end{array}$ & - & - & - & - & - & - & - & - & - & - & - \\
\hline $\begin{array}{l}\text { Low cord to } \\
\text { bed length }\end{array}$ & - & - & - & - & - & - & - & - & - & - & - \\
\hline
\end{tabular}




\section{APPENDIX E: \\ LEVEL I DATA FORM}


U. S. Geological Survey

Bridge Field Data Collection and Processing Form

Qa/Qc Check by: EW Date: $\underline{\mathbf{1 0 / 3 0 / 9 6}}$

\section{Structure Number}

REDSTH00360025 Date: $10 / 30 / 96$

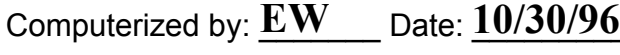

Reviewd by: $\quad$ RF Date: $\underline{\mathbf{6} / \mathbf{1 6} / 97}$

\section{A. General Location Descriptive}

1. Data collected by (First Initial, Full last name) R. BURNS

2. Highway District Number 01

Date $(M M / D D / Y Y) \underline{08} / \underline{01} / \underline{1996}$

County Bennington 003

Waterway $(I-6)$ West Branch Deerfield River

Route Number $\mathbf{C 3 0 3 6}$

Mile marker $\mathbf{0 0 0 0 0 0}$

Town Readsboro $\mathbf{5 8 6 0 0}$

Road Name -

Hydrologic Unit Code: $\mathbf{0 2 0 2 0 0 0 3}$

3. Descriptive comments:

Located 0.11 miles from junction with vt 100.

\section{B. Bridge Deck Observations}

\section{Surface cover... LBUS 6 \\ RBUS 4 \\ LBDS 5 \\ RBDS 5 \\ Overall 5}

(2b us,ds,lb,rb: 1- Urban; 2- Suburban; 3- Row crops; 4- Pasture; 5- Shrub- and brushland; 6- Forest; 7- Wetland)
5. Ambient water surface...US $\underline{2}$
UB 2
DS 1
(1- pool; 2- riffle)

6. Bridge structure type 1 (1- single span; 2- multiple span; 3- single arch; 4- multiple arch; 5-cylindrical culvert; 6- box culvert; or 7- other)
7. Bridge length $\underline{\mathbf{5 9}}$
(feet)
Span length $\underline{\mathbf{5 7}}$
(feet)
Bridge width 23.4 (feet)

\section{Road approach to bridge:}
8. LB 1 RB 1
( 0 even, 1- lower, 2- higher)
9. LB 1 $\mathrm{RB} \underline{1}$
(1- Paved, 2- Not paved)

10. Embankment slope (run / rise in feet / foot):

US left

US right

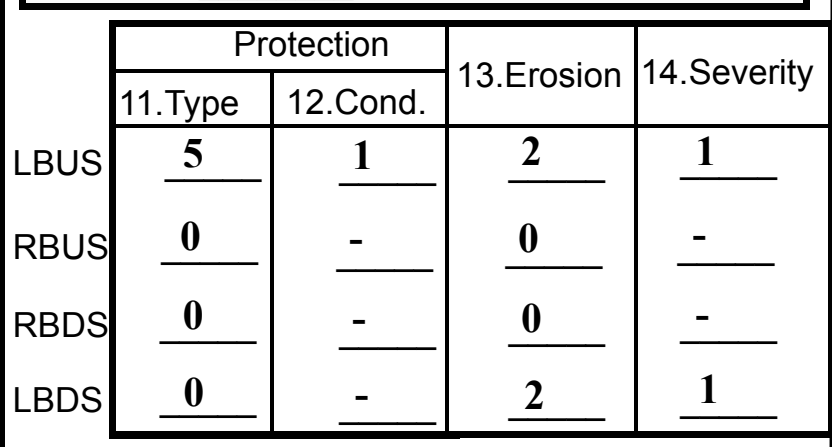

Bank protection types: 0- none; 1- < 12 inches;

2- < 36 inches; 3- < 48 inches;

4- < 60 inches; 5- wall / artificial levee

Bank protection conditions: 1- good; 2- slumped;

3- eroded; 4- failed

Erosion: 0 - none; 1- channel erosion; 2-

road wash; 3- both; 4- other

Erosion Severity: 0 - none; 1- slight; 2- moderate; 3- severe

\section{Channel approach to bridge (BF):}

15. Angle of approach: $\mathbf{5 0}$

16. Bridge skew: $\mathbf{5 0}$

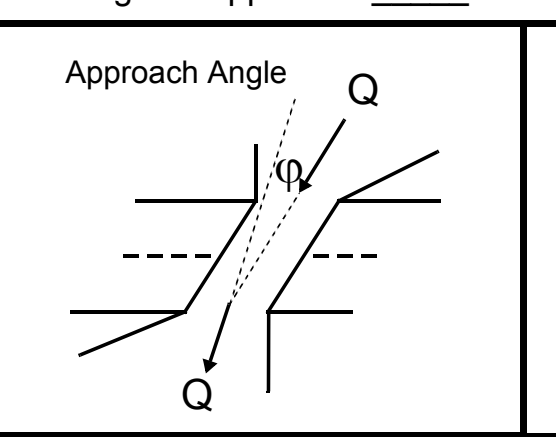

17. Channel impact zone 1:

Where? RB (LB, RB)

Range? 30 feet US

Channel impact zone 2:

Where? LB $(L B, R B)$

Range? $\underline{\mathbf{0}}$ feet US

Impact Severity: 0- none to very slight; 1- Slight; 2-Moderate; 3- Severe
Bridge Skew Angle

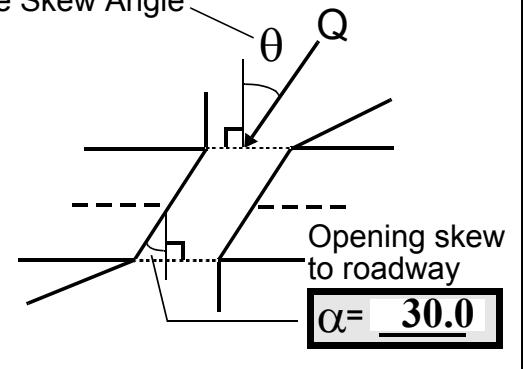

Exist? $\mathbf{Y}(Y$ or $N)$

Severity 2

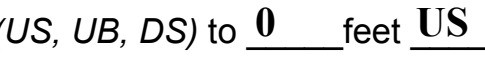

Exist? $\underline{\mathbf{Y}}(\mathrm{Y}$ or $N)$

Severity 2

$U B, D S)$ to $\underline{\mathbf{1 0}}$ feet $\underline{\mathbf{D S}}$ 
18. Bridge Type: 1a

1a- Vertical abutments with wingwalls

1 b- Vertical abutments without wingwalls

2- Vertical abutments and wingwalls, sloping embankment Wingwalls perpendicular to abut. face

3- Spill through abutments

4- Sloping embankment, vertical wingwalls and abutments

Wingwall angle less than $90^{\circ}$.
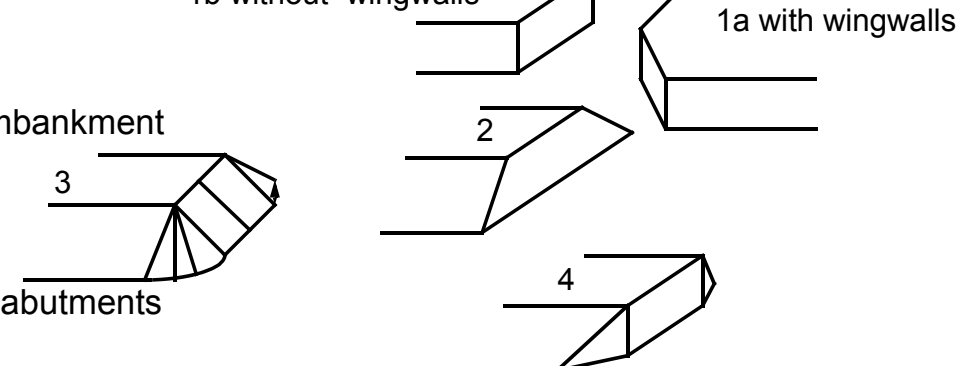

19. Bridge Deck Comments (surface cover variations, measured bridge and span lengths, bridge type variations, approach overflow width, etc.)

\#4. There are trees along the upstream left and right banks, as well as along the downstream right bank. The upstream right overbank is a mowed hay field. The downstream right and left overbanks have tall weeds and shrubs. The road is along the downstream left overbank. The upstream left bank has a wide area of trees and is forested beyond two bridge lengths from the stream with a clearing and gravel road beyond the forested area.

\section{Upstream Channel Assessment}

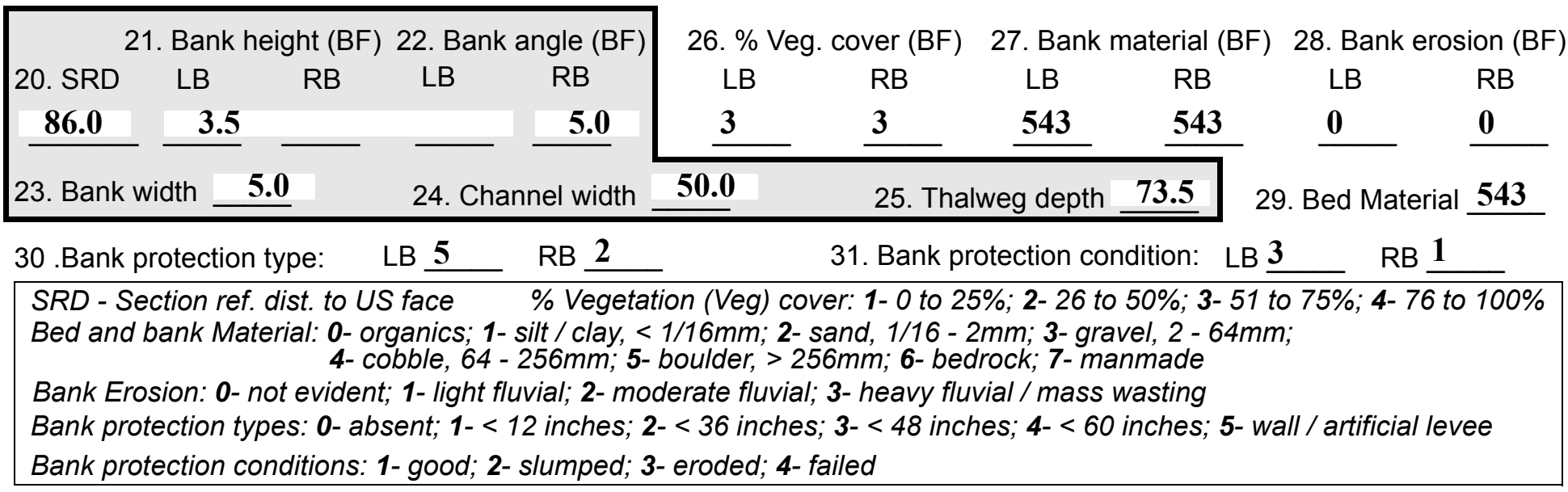

32. Comments (bank material variation, minor inflows, protection extent, etc.):

The bank protection on both the right and the left banks extends well beyond two bridge lengths; to at least 1000 feet upstream. On the upstream left bank, there are the remains of an old mill. Various stone walls extend along the bank and there is another wall closer to the gravel road. These walls have slumped and eroded in places. 

feet $\underline{\text { US }}$ (US, UB, DS) positioned $\mathbf{0}$ \%LB to $15 \%$ RB

37. Material: $\mathbf{5 4 3}$

38. Point or side bar comments (Circle Point or Side; Note additional bars, material variation, status, etc.):

39. Is a cut-bank present? $\mathbf{N}$ ( $Y$ or if $N$ type ctrl- $n c b)$ 40. Where? - $\quad$ (LB or RB)

41. Mid-bank distance: -

42. Cut bank extent: feet (US, UB) to feet (US, UB, DS)

43. Bank damage: (1- eroded and/or creep; 2- slip failure; 3- block failure)

44. Cut bank comments (eg. additional cut banks, protection condition, etc.):

NO CUT BANKS

\section{Is channel scour present? $\mathbf{Y}$ ( $Y$ or if $N$ type ctrl-n cs) 46. Mid-scour distance: 10 US}
47. Scour dimensions: Length $\underline{40}$
Width 7
Depth : 2
Position 60 \%LB to 100 \%RB

48. Scour comments (eg. additional scour areas, local scouring process, etc.):

Scour depth is 2 feet, based on a 1 foot thalweg. The scour is in front of the USRWW and RABUT. The midscour point is at the corner, but it is $\mathbf{1 0}$ feet upstream measured from the center of the upstream bridge face, due to 50 degree bridge skew. Scour is from 40 feet upstream to 0 feet upstream.

\section{Are there major confluences? $\mathbf{N}$}

51. Confluence 1: Distance Confluence 2: Distance 52. Enters on Enters on 54. Confluence comments (eg. confluence name):

NO MAJOR CONFLUENCES
50. How many? -

53. Type(1- perennial; 2- ephemeral) Type (1-perennial; 2- ephemeral) ( $(L B$ or $R B)$ (LB or $R B)$ (1-perennial; 2-ephemeral) 
65. Debris and Ice Is there debris accumulation?

67. Debris Potential ( 1- Low; 2- Moderate; 3- High)

69. Is there evidence of ice build-up? 1 (Y or $N)$

70. Debris and Ice Comments:

1
(Yor $N)$ 66. Where? $\mathbf{N}$

68. Capture Efficiency 1

(1- Upstream; 2- At bridge; 3-Both)

Ice Blockage Potential $\mathbf{N}$
(1- Low; 2- Moderate; 3- High)

(1-Low; 2- Moderate; 3- High)

\begin{tabular}{|l|c|c|c|c|c|c|c|c|}
\hline Abutments & $\begin{array}{c}\text { 71. Attack } \\
\angle \mathrm{BF})\end{array}$ & $\begin{array}{c}\text { 72. Slope } \\
(\mathrm{Qmax})\end{array}$ & $\begin{array}{l}\text { 73. Toe } \\
\text { loc. (BF) }\end{array}$ & $\begin{array}{c}\text { 74. Scour } \\
\text { Condition }\end{array}$ & $\begin{array}{c}\text { 75. Scour } \\
\text { depth }\end{array}$ & $\begin{array}{c}\text { 76. Exposure } \\
\text { depth }\end{array}$ & 77. Material & 78. Length \\
\hline LABUT & & $\mathbf{4 5}$ & $\mathbf{9 0}$ & $\mathbf{2}$ & $\mathbf{1}$ & $\mathbf{2}$ & $\mathbf{0}$ & $\mathbf{9 0 . 0}$ \\
\hline RABUT & $\mathbf{1}$ & - & $\mathbf{9 0}$ & & & $\mathbf{2}$ & $\mathbf{1}$ & $\mathbf{4 7 . 0}$ \\
\hline
\end{tabular}

Pushed: $L B$ or RB

Toe Location (Loc.): 0- even, 1- set back, 2- protrudes

Scour cond.: 0- not evident; 1- evident (comment); 2- footing exposed; 3-undermined footing; 4- piling exposed; 5- settled; 6- failed

Materials: 1- Concrete; 2- Stone masonry or drywall; 3- steel or metal; 4- wood

79. Abutment comments (eg. undermined penetration, unusual scour processes, debris, etc.):

2

0

1

The channel turns at the upstream bridge face. Scour along the left abutment extends along the entire base length. Scour is only along the upstream half of the right abutment. The downstream half of the right abutment has been filled in with stones (type-2).

80. Wingwalls:

Exist? Material? Scour Scour Exposure Angle? Length? Condition? depth? depth?

USLWW:

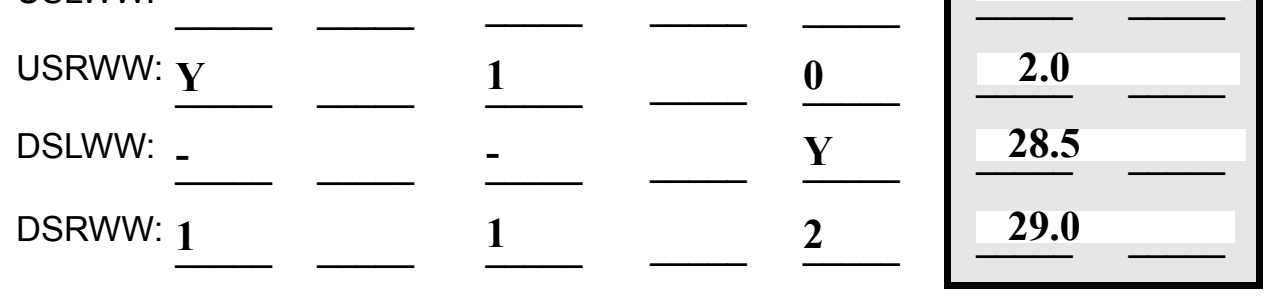

Wingwall materials: 1- Concrete; 2- Stone masonry or drywall; 3- steel or metal; 4- wood

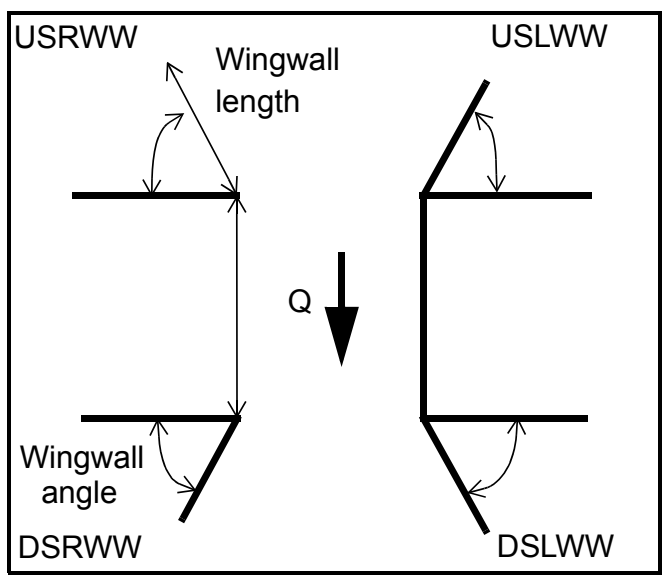

82. Bank / Bridge Protection:

\begin{tabular}{|l|l|l|l|l|l|l|l|l|}
\hline Location & USLWW & USRWW & LABUT & RABUT & LB & RB & DSLWW & DSRWW \\
\hline Type & - & $\mathbf{1}$ & $\mathbf{Y}$ & - & - & $\mathbf{1}$ & - & $\mathbf{1}$ \\
\hline Condition & $\mathbf{Y}$ & $\mathbf{1}$ & $\mathbf{1}$ & - & - & $\mathbf{2}$ & - & $\mathbf{3}$ \\
\hline Extent & $\mathbf{1}$ & - & $\mathbf{0}$ & $\mathbf{0}$ & $\mathbf{2}$ & $\mathbf{0}$ & $\mathbf{2}$ & - \\
\hline
\end{tabular}

Bank / Bridge protection types: 0- absent; 1- < 12 inches; 2- < 36 inches; 3- < 48 inches; 4- < 60 inches; 
83. Wingwall and protection comments (eg. undermined penetration, unusual scour processes, etc.):

-
-
-
-
-
2
1
3
2
1
1

Piers:

84. Are there piers? Th (Y or if N type ctrl-n pr)

\begin{tabular}{|l|r|r|l|l|l|l|l|}
\hline \multirow{2}{*}{$\begin{array}{l}85 . \\
\text { Pier no. }\end{array}$} & \multicolumn{3}{|c|}{ width (w) feet } & \multicolumn{5}{c|}{ elevation (e) feet } \\
\cline { 2 - 8 } & w1 & w2 & w3 & e@w1 & e@w2 & e@w3 \\
\hline Pier 1 & & $\mathbf{8 . 5}$ & & $\mathbf{7 5 . 0}$ & $\mathbf{1 0 . 0}$ & $\mathbf{1 8 . 0}$ \\
\hline Pier 2 & & & & $\mathbf{3 0 . 0}$ & $\mathbf{1 4 . 5}$ & $\mathbf{8 5 . 0}$ \\
\hline Pier 3 & $\mathbf{9 . 0}$ & - & - & - & - & - & w1 \\
\hline Pier 4 & - & - & - & - & - & - & w2 \\
\hline
\end{tabular}

\begin{tabular}{|l|l|l|l|l|}
\hline Level 1 Pier Descr. & \multicolumn{1}{|c|}{1} & \multicolumn{1}{|c|}{2} & \multicolumn{1}{|c|}{3} & \multicolumn{1}{|c|}{} \\
\hline 86. Location (BF) & e & wall & & by an \\
\hline 87. Type & upst & are & The & old \\
\hline 88. Material & ream & pro- & USL & stone \\
\hline 89. Shape & right & tecte & WW & wall. \\
\hline 90. Inclined? & wing & d on & is & \\
\hline 91. Attack $\angle$ (BF) & wall & the & pro- & Ther \\
\hline 92. Pushed & and & ends & tecte & e is \\
\hline 93. Length (feet) & - & - & - & - \\
\hline 94. \# of piles & dow & by & d on & also \\
\hline 95. Cross-members & nstre & bank & the & stone \\
\hline 96. Scour Condition & am & pro- & upst & in \\
\hline 97. Scour depth & left & tec- & ream & front \\
\hline 98. Exposure depth & wing & tion. & end & of \\
\hline
\end{tabular}

LFP, LTB, LB, MCL, MCM, MCR, RB, RTB, RFP

1- Solid pier, 2- column, 3- bent

1-Wood; 2- concrete; 3- metal; 4- stone

1- Round; 2- Square; 3- Pointed

Y-yes; N- no

$L B$ or $R B$

0- none; 1- laterals; 2- diagonals; 3- both

0- not evident; 1- evident (comment);

2- footing exposed; 3- piling exposed;

4- undermined footing; 5- settled; 6 - failed 
99. Pier comments (eg. undermined penetration, protection and protection extent, unusual scour processes, etc.):

the DSRWW, but is natural (not placed).

The channel impacts the USRWW at approximately a 50 degree angle. The streambed is scoured for approximately the entire base length of the wingwall.

The DSLWW is scoured along its entire base length and scour is caused by a combination of the flow along the LABUT and eddy currents.

N

$-$

$-$

100.

\section{E. Downstream Channel Assessment}

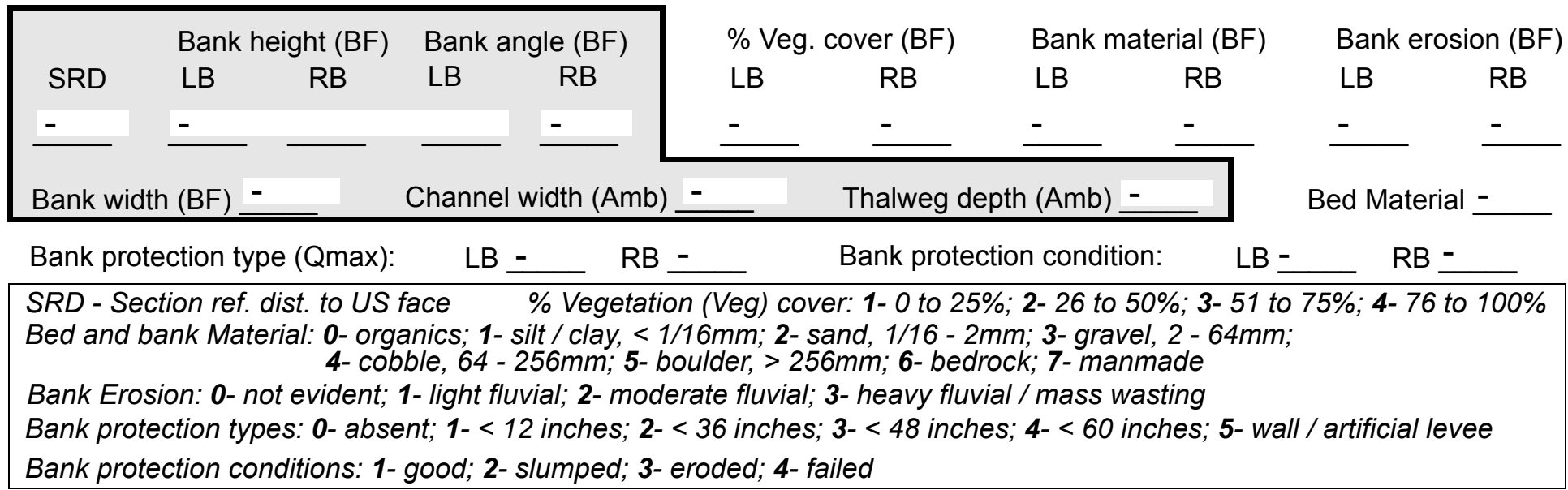

Comments (eg. bank material variation, minor inflows, protection extent, etc.):

$-$

$-$

$-$

$-$

-

$-$

$-$

$-$

$-$

101. Is a drop structure present? -__ ( $Y$ or $N$, if $N$ type ctrl-n ds) 102. Distance: ___ feet
103. Drop: - feet
104. Structure material:
(1- steel sheet pile; 2- wood pile; 3- concrete; 4- other)

105. Drop structure comments (eg. downstream scour depth):

$-$

$-$

$-$

$-$ 
106. Point/Side bar present? (Y or N. if $N$ type ctrl-n pb)Mid-bar distance: -

Mid-bar width: -

Point bar extent: feet -

(US, UB, DS) to feet (US, UB, DS) positioned $\%$ LB to $\% \mathrm{RB}$

Material:

Point or side bar comments (Circle Point or Side; note additional bars, material variation, status, etc.):

$-$

\section{NO PIERS}

Is a cut-bank present?

Cut bank extent: feet (US, UB, DS) to feet Where? (LB or $R B)$ Mid-bank distance:

Bank damage: (1- eroded and/or creep; 2- slip failure; 3- block failure)

Cut bank comments (eg. additional cut banks, protection condition, etc.): 1

2

543

543

Is channel scour present? $\mathbf{0}$ ( $Y$ or if $N$ type ctrl-n cs) Mid-scour distance: $\mathbf{0}$ Scour dimensions: Length $\underline{\mathbf{5 4 3}}$ Width $\underline{\mathbf{2}}$ Depth: 0 P Positioned 1 _ L LB to - $\%$ RB Scour comments (eg. additional scour areas, local scouring process, etc.):

There is a bridge 350 feet downstream for state route 100.

Left bank protection extends from the end of the downstream left wingwall to the upstream face of the state route 100 bridge. It is dumped native stone.

Are there major confluences? ( $Y$ or if $N$ type ctrl-n $m c)$

Confluence 1: Distance chan Enters on nel ( $L B$ or $R B)$ Enters on slig ( $L B$ or $R B)$

Confluence 2: Distance ds

Confluence comments (eg. confluence name):

downstream and the downstream right bank is very low and flat. There is a lot of stone among the vegetation on the bank and water will go over the bank during high flow.

\section{F. Geomorphic Channel Assessment}

107. Stage of reach evolution

1- Constructed

2- Stable

3- Aggraded

4- Degraded

5- Laterally unstable

6- Vertically and laterally unstable 
108. Evolution comments (Channel evolution not considering bridge effects; See HEC-20, Figure 1 for geomorphic descriptors):

$\mathbf{N}$

NO DROP STRUCTURE 


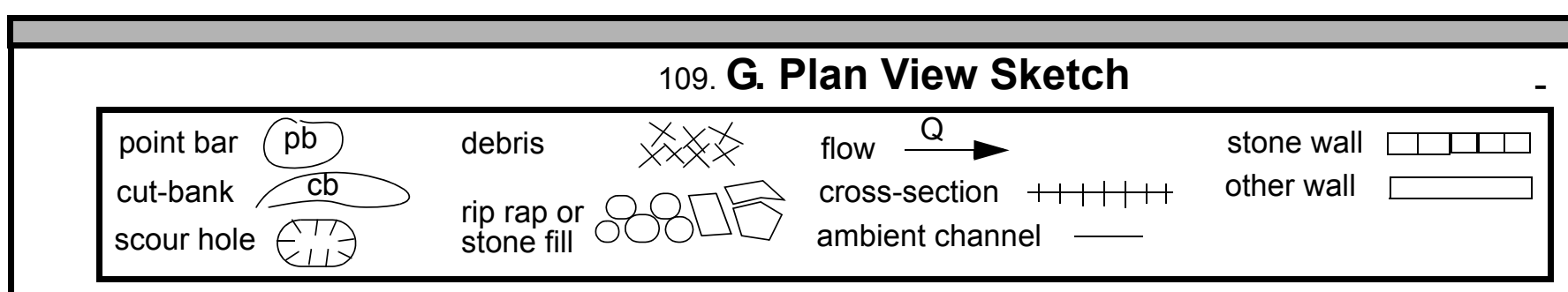


APPENDIX F:

SCOUR COMPUTATIONS 
SCOUR COMPUTATIONS

\begin{tabular}{|c|c|c|c|}
\hline Structure Number: REDSTH00360025 & & Town : & Readsboro \\
\hline Road Number: & & County: & Bennington \\
\hline Stream: West Branch Deerfield Rive & & & \\
\hline Initials RHF & Checked: & EMB & \\
\hline Analysis of contraction scour, liv & -bed or $\mathrm{cl}$ & lear wa & \\
\hline Critical Velocity of Bed Material & converted & to Engli & sh units) \\
\hline $\begin{array}{l}\mathrm{VC}=11.21 * \mathrm{Y} 1^{\wedge} 0.1667 * \mathrm{D} 50^{\wedge} 0.33 \text { with Ss } \\
\text { (Richardson and others, } 1995, \mathrm{p} .28\end{array}$ & $\begin{array}{l}=2.65 \\
\text {, eq. } 16)\end{array}$ & & \\
\hline Approach Section & & & \\
\hline Characteristic & $100 \mathrm{yr}$ & $500 \mathrm{yr}$ & other $Q$ \\
\hline Total discharge, cfs & 3020 & 4750 & 3580 \\
\hline Main Channel Area, ft2 & 490 & 757 & 561 \\
\hline Left overbank area, ft2 & 226 & 451 & 272 \\
\hline Right overbank area, ft2 & 24 & 800 & 120 \\
\hline Top width main channel, ft & 81 & 81 & 81 \\
\hline Top width L overbank, ft & 53 & 92 & 57 \\
\hline Top width $\mathrm{R}$ overbank, ft & 68 & 319 & 153 \\
\hline D50 of channel, ft & 0.3829 & 0.3829 & 0.3829 \\
\hline D50 left overbank, ft & -- & -- & -- \\
\hline D50 right overbank, ft & -- & -- & -- \\
\hline Y1, average depth, MC, ft & 6.0 & 9.3 & 6.9 \\
\hline y1, average depth, LOB, ft & 4.3 & 4.9 & 4.8 \\
\hline Y1, average depth, ROB, ft & 0.4 & 2.5 & 0.8 \\
\hline Total conveyance, approach & 60615 & 187554 & 80505 \\
\hline Conveyance, main channel & 47068 & 97201 & 58949 \\
\hline Conveyance, LOB & 13105 & 35446 & 17755 \\
\hline Conveyance, ROB & 442 & 54908 & 3799 \\
\hline Percent discrepancy, conveyance & 0.0000 & -0.0005 & 0.0025 \\
\hline Qm, discharge, $\mathrm{MC}$, cfs & 2345.1 & 2461.7 & 2621.4 \\
\hline Q1, discharge, LOB, Cfs & 652.9 & 897.7 & 789.6 \\
\hline Qr, discharge, ROB, Cfs & 22.0 & 1390.6 & 168.9 \\
\hline $\mathrm{Vm}$, mean velocity $\mathrm{MC}$, ft/s & 4.8 & 3.3 & 4.7 \\
\hline VI, mean velocity, LOB, ft/s & 2.9 & 2.0 & 2.9 \\
\hline Vr, mean velocity, ROB, ft/s & 0.9 & 1.7 & 1.4 \\
\hline Vc-m, crit. velocity, MC, ft/s & 11.0 & 11.8 & 11.2 \\
\hline Vc-l, crit. velocity, LOB, ft/s & $E R R$ & ERR & ERR \\
\hline Vc-r, crit. velocity, ROB, ft/s & ERR & $\mathrm{ERR}$ & ERR \\
\hline Results & & & \\
\hline Live-bed(1) or Clear-Water(0) Contr & action $\mathrm{Scc}$ & our? & \\
\hline Main Channel & 0 & 0 & 0 \\
\hline Left Overbank & $\mathrm{N} / \mathrm{A}$ & $\mathrm{N} / \mathrm{A}$ & $\mathrm{N} / \mathrm{A}$ \\
\hline Right Overbank & $\mathrm{N} / \mathrm{A}$ & $\mathrm{N} / \mathrm{A}$ & $\mathrm{N} / \mathrm{A}$ \\
\hline RING & & & \\
\hline D90 & 1.206 & 1.206 & 1.206 \\
\hline
\end{tabular}


D95

Critical grain size,Dc, ft

Decimal-percent coarser than DC

Depth to armoring, ft

$\begin{array}{lll}1.853 & 1.853 & 1.853 \\ 1.0591 & 0.4834 & 1.1200 \\ 0.1135 & 0.3436 & 0.1079 \\ 24.82 & 2.77 & 27.78\end{array}$

Clear water Contraction Scour in MAIN CHANNEL

$\mathrm{Y} 2=\left(\mathrm{Q} 2 \wedge 2 /\left(131 * \operatorname{Dm}^{\wedge}(2 / 3) * \mathrm{~W} 2 \wedge 2\right)\right)^{\wedge}(3 / 7) \quad$ Converted to English Units ys=y2-y_bridge

(Richardson and others, 1995, p. 32, eq. 20, 20a)

Approach Section

Main channel Area, ft2

Main channel width, ft

y1, main channel depth, ft

Bridge Section

(Q) total discharge, cfs

(Q) discharge thru bridge, cfs

Main channel conveyance

Total conveyance

Q2, bridge MC discharge, cfs

Main channel area, ft2

Main channel width (skewed), ft

Cum. width of piers in MC, ft

$W$, adjusted width, ft

Y_bridge (avg. depth at br.), ft

Dm, median $(1.25 * D 50)$, ft

y2, depth in contraction, ft

ys, scour depth (y2-ybridge), ft

Q100 Q500 Qother

\begin{tabular}{lll}
490 & \multicolumn{1}{c}{757} & \multicolumn{1}{l}{561} \\
81 & 81 & 81 \\
6.05 & 9.35 & 6.93
\end{tabular}

$\begin{array}{lll}3020 & 4750 & 3580 \\ 3020 & 4398 & 3580 \\ 16195 & 29341 & 19307 \\ 16195 & 29341 & 19307 \\ 3020 & 4398 & 3580 \\ 237 & 441 & 265 \\ 46.8 & 47.1 & 46.8 \\ 0.0 & 0.0 & 0.0 \\ 46.765 & 47.11 & 46.765 \\ 5.06 & 9.37 & 5.67 \\ 0.478625 & 0.478625 & 0.478625 \\ 5.44 & 7.46 & 6.29 \\ 0.38 & -1.91 & 0.62\end{array}$

Pressure Flow Scour (contraction scour for orifice flow conditions) $\mathrm{Hb}+\mathrm{Ys}=\mathrm{Cq} * \mathrm{qbr} / \mathrm{VC} \quad \mathrm{Cq}=1 / \mathrm{Cf} * \mathrm{CC} \quad \mathrm{Cf}=1.5 * \mathrm{Fr}^{\wedge} 0.43 \quad(<=1)$

Chang Equation CC=SQRT $[0.10(\mathrm{Hb} /(\mathrm{ya}-\mathrm{w})-0.56)]+0.79 \quad(<=1)$

(Richarson and others, 1995, p. 145-146)

Q100 Q500 OtherQ

Q, total, cfs $\quad 3020 \quad 4750 \quad 3580$

Q, thru bridge, cfs $\quad 3020 \quad 4395 \quad 3580$

Total Conveyance, bridge $\quad 16195 \quad 29341 \quad 19307$

Main channel(MC) conveyance, bridge $16195 \quad 29341 \quad 19307$

Q, thru bridge MC, Cfs $\quad 3020 \quad 4395 \quad 3580$

$\begin{array}{llll}\mathrm{V} C, \text { critical velocity, ft/s } & 10.99 & 11.81 & 11.24\end{array}$

Vc, critical velocity, m/s $\quad 3.35 \quad 3.60 \quad 3.43$

Main channel width (skewed), ft $46.8 \quad 47.1 \quad 46.8$

Cum. width of piers in MC, ft $0.0 \quad 0.0 \quad 0.0$

W, adjusted width, ft

qbr, unit discharge, ft2/s

qbr, unit discharge, $\mathrm{m} 2 / \mathrm{s}$

Area of full opening, ft2

$\mathrm{Hb}$, depth of full opening, ft

$\begin{array}{lll}46.8 & 47.1 & 46.8\end{array}$

$\begin{array}{lll}64.6 & 93.3 \quad 76.6\end{array}$

$\begin{array}{lll}6.0 & 8.7 & 7.1\end{array}$

$236.7 \quad 441.3 \quad 265.2$

$\begin{array}{lll}5.06 & 9.37 & 5.67\end{array}$

$\mathrm{Hb}$, depth of full opening, $m$

$\begin{array}{lll}1.54 & 2.86 & 1.73\end{array}$

Fr, Froude number, bridge MC

$0 \quad 0.62$

0

Cf, Fr correction factor $(<=1.0) \quad 0.00 \quad 1.00 \quad 0.00$ 


$\begin{array}{llll}\text { Elevation of Low Steel, ft } & 0 & 497.81 & 0 \\ \text { Elevation of Bed, ft } & -5.06 & 488.44 & -5.67 \\ \text { Elevation of Approach, ft } & 0 & 500.57 & 0 \\ \text { Friction loss, approach, ft } & 0 & 0.17 & 0 \\ \text { Elevation of WS immediately US, ft } 0.00 & 500.40 & 0.00 \\ \text { ya, depth immediately US, ft } & 5.06 & 11.96 & 5.67 \\ \text { ya, depth immediately US, m } & 1.54 & 3.64 & 1.73 \\ \text { Mean elevation of deck, ft } & 0 & 501.77 & 0 \\ \text { w, depth of overflow, ft (>=0) } & 0.00 & 0.00 & 0.00 \\ \text { CC, vert contrac correction (<=1.0) } 1.00 & 0.94 & 1.00 \\ \text { Ys, depth of scour, ft } & \text { N/A } & -0.96 & \text { N/A } \\ \text { Comparison of Chang and Laursen results (for unsubmerged orifice flow) } \\ \text { y2, from Laursen's equation, ft } 5.4391397 .459696 & 6.292925 \\ \text { Full valley WSEL, ft } & 0 & 494.02 & 0 \\ \text { Full valley depth, ft } & 5.061478 & 5.577438 \text { 5.670908 } \\ \text { Ys, depth of scour (y2-yfullv), ft N/A } & 1.882259 \text { N/A }\end{array}$

Abutment scour

Froehlich's Abutment Scour

$\mathrm{Ys} / \mathrm{Y} 1=2.27 * \mathrm{~K} 1 * \mathrm{~K} 2 *\left(\mathrm{a}^{\prime} / \mathrm{Y} 1\right)^{\wedge} 0.43 * \mathrm{Fr} 1 \wedge 0.61+1$

(Richardson and others, 1995, p. 48, eq. 28)

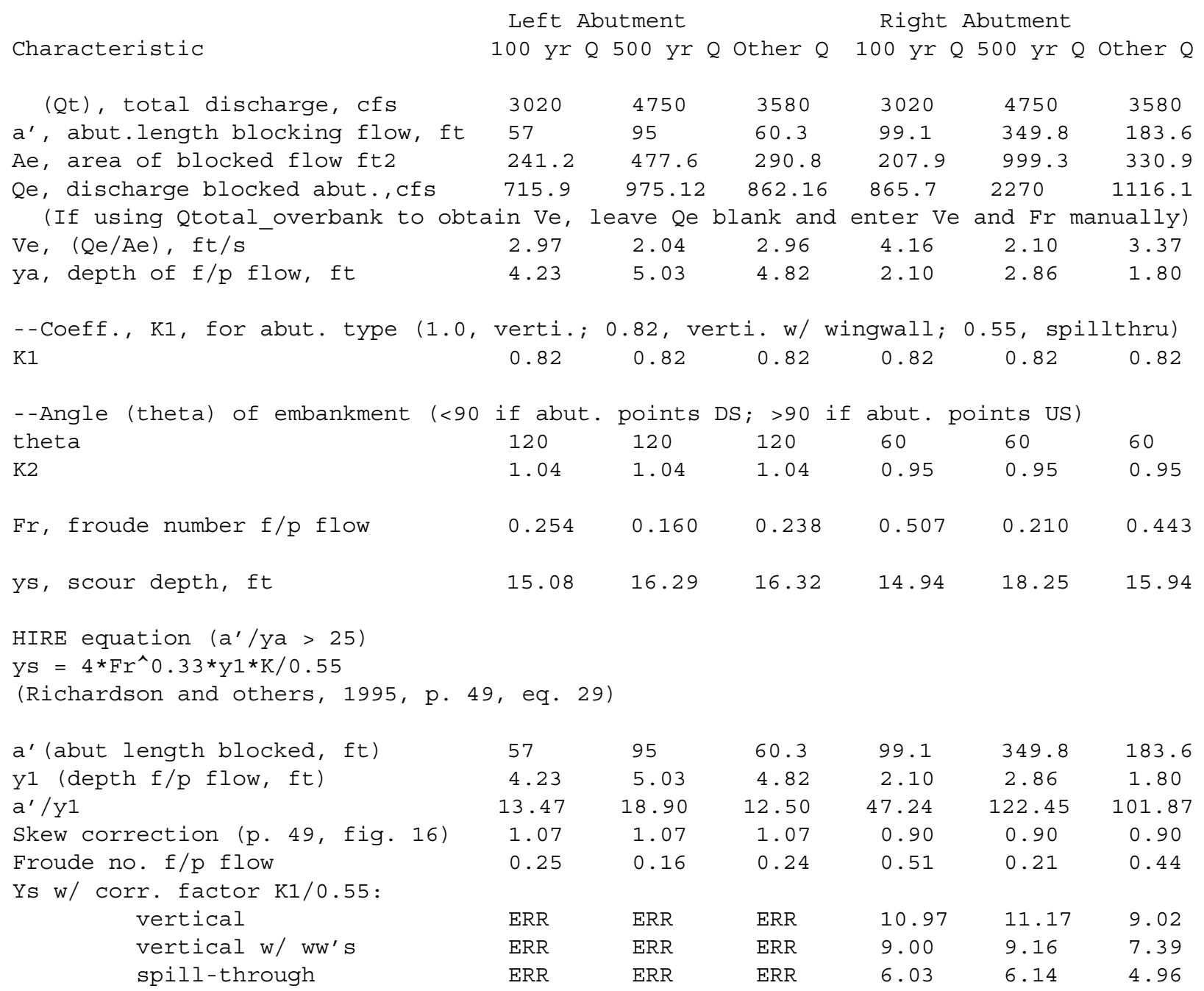




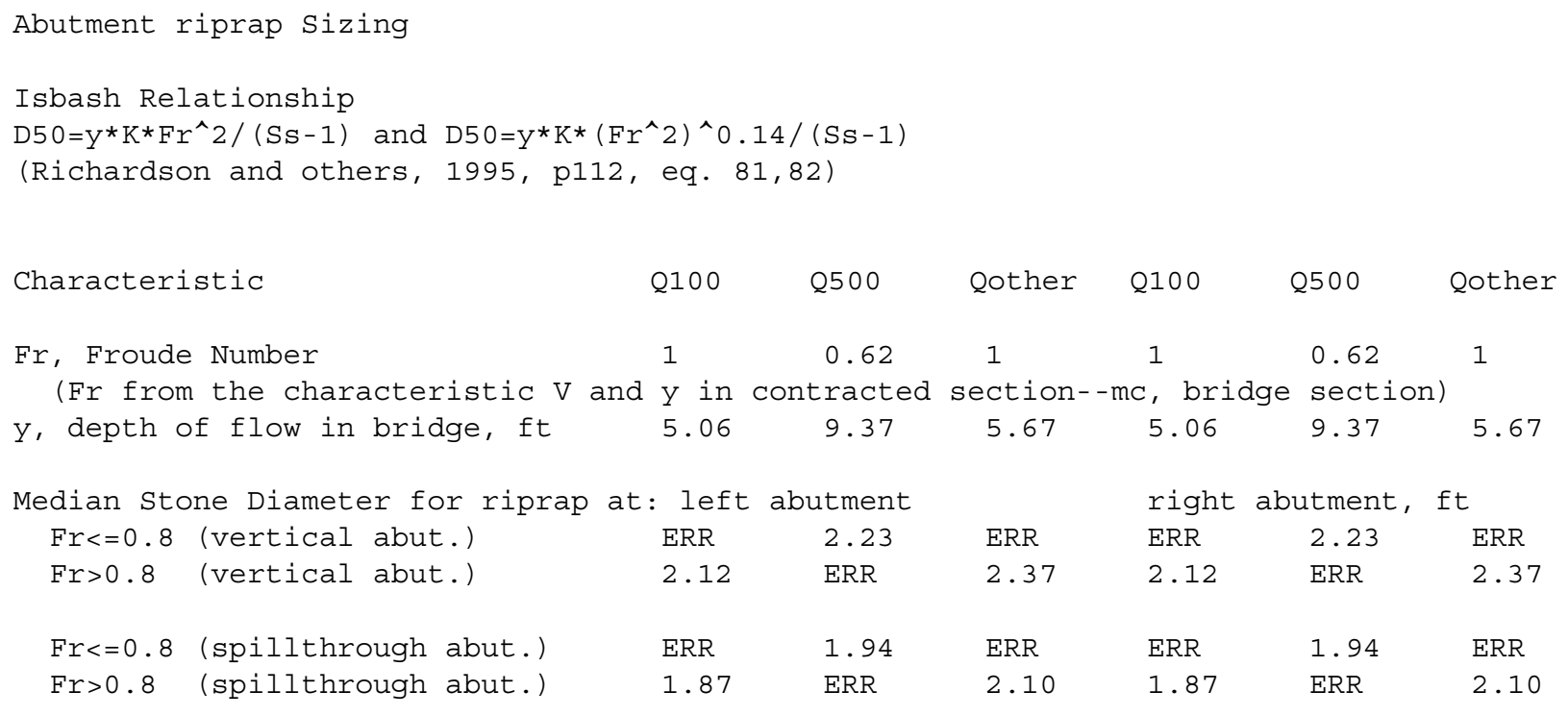

